\title{
土潩洗浄による放射性Cs污染土壤の 浄化・減容化処理の物質収支と性能評価
}

\author{
毛利 光男 ${ }^{1} \cdot$ 馬場 直紀 ${ }^{2} \cdot$ 土田 充 $^{3} \cdot$ 中嶋 卓磨 ${ }^{4}$ \\ 1正会員 清水建設株式会社 エンジニアリング事業本部 土壌環境事業部 \\ （ 干104-8370 東京都中央区京橋2-16-1） \\ E-mail: mouri@shimz.co.jp \\ 2清水建設株式会社 エンジニアリング事業本部 土壌環境事業部（同上） \\ E-mail: n-baba@shimz.co.jp \\ 3清水建設株式会社 エンジニアリング事業本部 土壌環境事業部（同上） \\ E-mail:m.tsuchida@shimz.co.jp \\ 4清水建設株式会社 エンジニアリング事業本部 土壌環境事業部（同上） \\ E-mail: takuma@shimz.co.jp
}

\begin{abstract}
本研究では, 土壤洗浄による放射性Cs污染土䁃の浄化・減容化効果を把握することを目的に, 各洗浄プ ロセスの放射性Cs量の収支を検討した上で，トレードオフの関係にある浄化・減容化の評価を行なった。 土壌洗浄による浄化効果は高 $<, 20,000 \mathrm{~Bq} / \mathrm{kg}$ 前後の元土壤から概衫 $3,000 \mathrm{~Bq} / \mathrm{kg}$ 以下の浄化産出物(洗浄土 十粗粒子分)が得られること, 減容化効果も高く, 元土壌の $70 \sim 80 \%$ を浄化産出物として回収できることが 判明した。.また, 元土壌中の有機物のほとんどが濃縮残渣に集約され, 浄化産出物の強熱減量は $2 \sim 3 \%$ と 低い值となった．分級処理に化学的洗浄処理であるスクラビング・フローテーションを追加することは, 高い除去率と高い減容率の両立に極めて有効であると考えられた。
\end{abstract}

Key Words : radiocesium contaminated soil, soil washing, remediation and volume reduction, mass balance analysis, scrubbing-flotation, performance evaluation

\section{1. はじめに}

福島県の除染事業によって放射性Cs污染土袞と廃棄 物の集積が進んでおり，環境省によると総量は 1,500 2,800万 $\mathrm{m}^{3}$ になると推定されている1), 2). 膨大な污染土袞 などを保管する中間貯蔵施設の建設には莫大な建設費用 が必要となるため, 污染土壌や廃暂物などを効率的に浄 化・減容化する技術が重要であると考えられる．放射性

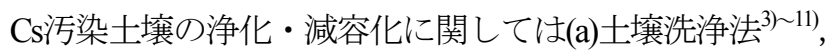
(b) 薬剤抽出法 ${ }^{12,}$, 13), (c)加熱処理法 ${ }^{14,}$, 15)などの技術開発が 進められている，筆者らは，膨大な量の放射性CS污染土 壤の減容化を迅速かつ効率良く進めるためには，大量処 理に適した土袞洗浄法を核とした浄化・減容化システム が最も有効であると考えている．土壌洗浄法は，重金属， 鉱物油，農薬など多くの物質に適用可能な代表的な浄

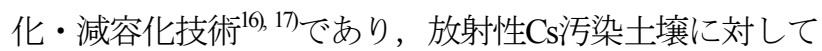
も室内実験と除染技術実証事業18)において多くの検討と
実証が行われてきた

今までに報告された土壤洗浄による浄化・減容化の 実験的検討の多くは，主に分級洗浄(湿式フルイ，八イ ドロサイクロンなど)に研磨処理(土壤表面の磨砕)を追加 したものであり，放射性Cs除去率を向上させることを目 的に行なわれてきた。一般に分級洗浄や研磨処理を用い た浄化法では，放射性CS除去率と洗浄土の回収率(=減容 率)はトレードオフの関係にある。すなわち，高い放射 性CS除去率を追求するために分級径を大きくしたり，土 袞粒子表面を過度に研磨すると, 濃縮残渣(脱水ケーキ) の割合が増大し回収できる洗浄土が大幅に減少するため, 減容化効果が大きく低下寸る。この観点から, 浄化・減 容化を合理的に進めるためには，浄化技術のさらなる革 新もさることながら，土袞洗浄法による放射性Cs污染土 壤全体の浄化・減容化効果，すなわちトレードオフの関 係にある放射性CS除去率と減容率の両方を定量的に理解 することが重要と考える. 
本研究は, 土壌洗浄による放射性Cs污染土壌全体の 浄化効果と減容化効果の両面を把握することを目的に実 施した. 本研究で対象とした土㙵洗浄法は, 分級処理の みによる従来の洗浄法と異なり, 土壤粒子と污染物質の 界面化学的性質の違いを利用して污染物質を選択的に分 離する洗浄技術(スクラビング・フローテーション)を備 えている9 10). 最初に多数の放射性CS污染土壌(福島県内 の運動場土壤と住宅地等の除染除去土壤)の特性(含有放 射能量, 強熱減量, 粒度分布など)を把握した上で一連 の土壌洗浄実験を行なった. 次に, 各洗浄プロセスの放 射性Cs量の収支を検討した上で，本土壌洗浄法による浄 化・減容化効果の評価を行なった．特に，(a)分級処理の みの場合と分級処理に加えて洗浄処理を行なった場合の 除去率と濃縮残椬発生量の関係，および(b)浄化産出物 と濃縮残椬の発生量と放射性Cs量の分配割合については 詳しい考察を行なった. 最後に, 元土壤中の放射性Csが ぞのように洗浄土, 粗粒子分, 濃縮残渣一分配されるの かを表示し, 本土壌洗浄法による浄化・減容化効果の理 解を図った. 尚, 本論文においては洗浄処理の対象とな る污染土袞を元土壤(feed soil), 浄化された土壌を洗浄土 (clean sand), 放射性Csが濃縮された脱水ケーキを濃縮残 渣(sludge cake)と記している.

\section{2. 既往の知見, 本研究の土袞洗浄法の概要}

\section{（1）土壤洗浄による浄化・減容化の実験例}

放射性Csはその多くが細粒子分(粘土・シルト)に付 着・吸着しているため, 細粒子分を分離することによっ て，土壌から放射性Csを効率良く除去寸ることが十分可 能であると考えられている3 ${ }^{3111}$. 井出ら ${ }^{31}$ は福島県内の 運動場土壌(1,300〜 46,000 Bq $\mathrm{kg}$ の3試料)を対象に分級洗 浄の室内試験を行ない，(a)含有放射能量の除去率が概衩 75\%であること，(b)除去率をさらに上げるには研磨処理 (ロッドミルなど)を組み入れることが有効であることを 報告している．舟川ら ${ }^{4}$ は植物が混入した放射性CS污染 土壤 $(5,400 \sim 12,600 \mathrm{~Bq} / \mathrm{kg}$ の試料)の多段階土畩洗浄処理 試験を行ない，(a)洗浄土の放射性Cs濃度は1,300～3,300 Bq $\mathrm{kg}$ まで低減し，放射性Cs除去率は73〜90\%であること， (b)元土壌の粘土・シルト分の割合が $30 \sim 45 \%$ の場合，洗 浄土の回収率は 50 ～60\%であること，(c)污染土壤中の植 物片には放射性Csが高濃度で吸着していること, (d)土 壤表面を摩砕することで浄化効率が向上寸ることを述心゙ ている. 中島ら 対して分級洗浄の実験を行ない，(a)ロータリー式の分級 洗浄による一次洗浄土の放射性Cs除去率は58～83\% (ave. 68\%)であること，(b)キャビテーションジェットによる 研磨洗浄を追加した二次処理土の放射性Cs除去率は80〜
93\% (ave. 85\%)まで向上寸ることを報告している. 他の研 磨方法としては, ジェットポンプによる磨洗の, コンク リート吹付機を用いた砂洗浄 ${ }^{7}$, ポットミルを用いた磨 砕洗浄)などが報告されている. 上記のように分級洗浄 に物理的な研磨処理を追加することは，放射性 $\operatorname{Cs} の$ 低減 には効果的であるが，摩耗粒子が多量に発生するため減 容化にはマイナスに働くという久点を有している.

\section{(2) 本研究の土袞洗浄法の概要}

本研究の土壤洗浄法では, 物理的な研磨処理ではなく, 化学的な洗浄処理であるスクラビング・フローテーショ ンを使用した，後述するように，薬剤を用いたスクラビ ングによって土壌粒子表面に付着しているCs吸着粒子が 効果的に剥離されるため, 摩耗粒子の発生を抑制するこ とができる. 本研究の土壌洗浄法のフローを図-1に示す. 2段湿式フルイ(wet screens)によって元土壌(feed soil)は, $2 \mathrm{~mm}$ 以上の㗂・粗砂分(coarse fractions) と $2 \mathrm{~mm}$ 以下の土畩 (feed $<2 \mathrm{~mm})$ に篩い分けられる. $2 \mathrm{~mm}$ 以下の土猿スラリー は, ハイドロサイクロン(hydrocyclone, 分級径: $63 \mu \mathrm{m}$, 滞留 時間: 数秒)によってオーバーフロー( $\mathrm{OF}$, 細粒子分 $)$ とアン ダーフロー(UF, 砂・細砂分)に分級される. アンダーフ ロー中の砂・細砂分は，スクラバー(scrubber, 滞留時間: 4 〜6分)において複数の薬剤によって表面処理された後, スクラビングによって土壌粒子表面から付着しているCs 吸着粒子や有機物等が効果的に剥離される. 続いて, フ ローテーションセル(滞留時間: 10～15分)に入り, 起泡剤 (frother)が添加されフローテーションが行われる. ここで は, 雲母類などのCs吸着粒子や有機物等は, 土壤粒子と

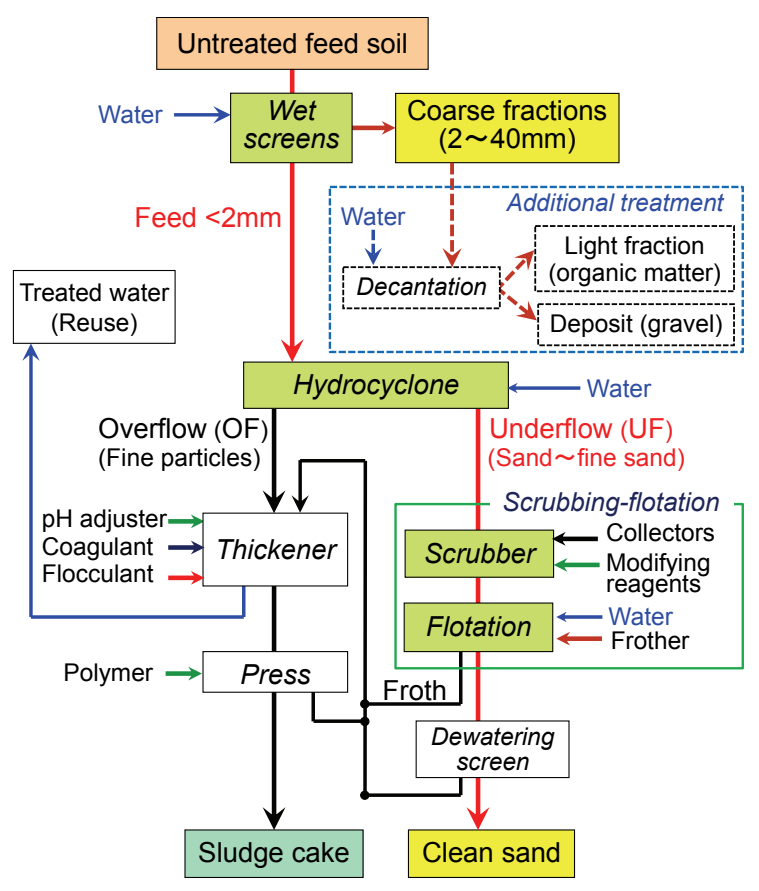

図-1 放射性 Cs 污染土壤の洗浄処理フロー 
の界面化学的性質の差を利用して選択的に分離され，気 泡と共に液表面まで上昇しフロス(froth)として系外一除 去される. 洗浄された砂・細砂分は, 脱水工程を経て洗 浄土(clean sand)となる.オーバーフローとフロスに含ま れる細粒子分は, 凝集沈殿とプレス脱水を経て濃縮残椬 (sludge cake)となる．なお，一連のスクラビング・フロー テーション(scrubbing-flotation)の工程では, 捕収剤, $\mathrm{pH}$ 調 整剂, 活性剂, 抑制剂, 起泡剤などが適宜使用される.

\section{3. 実験内容と方法}

本研究では, 福島県の双葉郡の広野町, 浪江町, 川内 村, 相馬郡の飯舘村, 南相馬市, 田村市, 伊達市の学校 の運動場(playground, $\mathrm{PG})$ の表層部( $(0 \sim 5 \mathrm{~cm})$ から採取した土 壤(11 試料)と広野町周辺の住宅地等(residential area, RA)を 除染した際に表層部( $(0 \sim 5 \mathrm{~cm})$ を剥ぎ取った土壌(10 試料), すなわち運動場土㙥(soil-PG) と住宅地等の除染除去土壌 (soil-RA)の計 21 試料を対象に実験を行なった.

これらの土壌試料の基礎的な性状と放射性Csの分布特 性を把握するために，元土壤(feed soil)の含有放射能量と 強熱減量(ignition loss)の分析, 粒度分布試験(grain-size distribution test)を実施した. 強熱減量の分析は，植物片や腐 植質などの有機物量を把握するために行なった８ 8試料 の soil-PG $(5,640 \sim 69,500 \mathrm{~Bq} \mathrm{~kg})$ と 6 試料の soil-RA $(13,200 \sim$ $26,300 \mathrm{~Bq} / \mathrm{kg}$ )の計14試料について土壤洗浄試験(soil washing test)を行ない，洗浄プロセスにおける放射性Csの分離・ 除去過程を調べた．次に，各洗浄プロセスの放射性Csの 収支を検討した上で，2mm以上の粗粒子分を含む放射性 Cs污染土壤全体の浄化・減容化効果の評価を行なった.

Soil-RAの2 4 $4 \mathrm{~mm}$ 粗粒子分には, 多数の軽質分(植物片 等の有機物)が混入していた。このため，ログウォッシ ヤー(log washer $)^{19)}$ の使用を想定した傾斜法(decantation)によ る軽質分の分離試験を追加した.

土袞試料別に実施した実験項目を表-1に整理して示す。

\section{(1) 含有放射能量と強熱減量の分析}

含有放射能量の分析では, SEIKO EG\&G社 HPGe半導 体検出器(GEM-35200-P, 33-TP30842A), SEIKO EG\&G社 MFG-DSPEC-JR-2.0型波高分析装置, CANBERRA社 INSP14型波高分析装置が使用された．本論文における含有放 射能量は試料測定時点での值であり, 有効数字 3 栴の值 で表示した. 強熱減量はJIS A1226に従って分析された.

土壌試料の含有放射能量と強熱減量の分析は, 外部の 分析機関へ依頼した.

\section{(2) 粒度分布試験}

2段の金網フルイ(上段: $4 \mathrm{~mm}$,下段: $2 \mathrm{~mm}$ ) を有する(株)興
和工業所の円形振動フルイ機(KGCR-500-2D)を用いて, 湿式で元土壤を $2 \mathrm{~mm}$ 以上の粗粒子分と $2 \mathrm{~mm}$ 以下の土壌に 分級した. 粒度分布試験では, $2 \mathrm{~mm}$ 以下の土壤を対象に, Retsch社の振動フルイ機(AS200) と篩目が $38 \mu \mathrm{m}, 63 \mu \mathrm{m}$, $125 \mu \mathrm{m}, 250 \mu \mathrm{m}, 500 \mu \mathrm{m}, 1 \mathrm{~mm}$, および2mmの金網フルイを用 いて湿式で篩分けを行い，対象試料の粒度分布を求めた。 篩目が $D_{L}$ と $D_{U}$ のフルイによって分けられた土壌粒子の 代表粒子径 $D_{M}$ は式(1)より求めた ${ }^{20}$.

$$
D_{M}=\sqrt{\left(D_{L}^{2}+D_{U}^{2}\right) / 2}
$$

例えば， $38 \mu \mathrm{m}$ 未満の土㙵の代表粒子径は， $D_{L}=0 \mu \mathrm{m}$ ， $D_{U}=38 \mu \mathrm{m}$ より $D_{M}=26.8 \mu \mathrm{m}$ となる.

\section{(3) 土袞洗浄試験}

サイクロン試験はMozley社のハイドロサイクロン $(50 \%$ 分級径: $63 \mu \mathrm{m})$ を用いて，土壌スラリーの供給圧力が 0.1 $\mathrm{MPa}$ の設定下で行った. 土壌スラリーは図-2に示すよう にサイクロン内部で分級され，上部よりオーバーフロー (OF, $63 \mu \mathrm{m}$ 未満の細粒子分を含むスラリー)が，下部より アンダーフロー(UF, $63 \mu \mathrm{m} \sim 2 \mathrm{~mm}$ の砂・細砂分を含むス ラリー)が流出する. $2 \mathrm{~mm}$ 以下の土壤スラリー, OF, UFの 固形物率(DS)をそれぞれDS $S_{\text {fead }} D S_{O F}, D S_{U F}$ とし, $\mathrm{OF}$ と $\mathrm{UF}$ の重量比を $1-x: x$ とすると, 式(2)の関係式が得られる.

$$
D S_{\text {feed }}=D S_{U F} \cdot x+D S_{O F} \cdot(1-x)
$$

スクラビング・フローテーション試験は, Denver社の フローテーション試験機を用いて行った. UF中の砂・ 細砂分は, 試験機のセル内で捕収剂(collector)などの薬剤 と混合され，スクラビングによって砂粒子の表面からCs を吸着した污染粒子が効果的に剥離される(図-3(A)). 次 に，セル内に気泡剤(frother)が添加されフローテーション が行われる. 粒子表面が疎水化された污染粒子は選択的 に気泡へ吸着し，液面まで連行されフロス層を形成する. 放射性Csを吸着した污染粒子はフロス(froth) として掻き出 されることで系外一除去される(図-3(B)). 捕収剂は，対 象の污染粒子の表面に吸着して粒子表面を疎水化する界 面活性剂である。起泡剤は，界面活性が高く特定の吸着

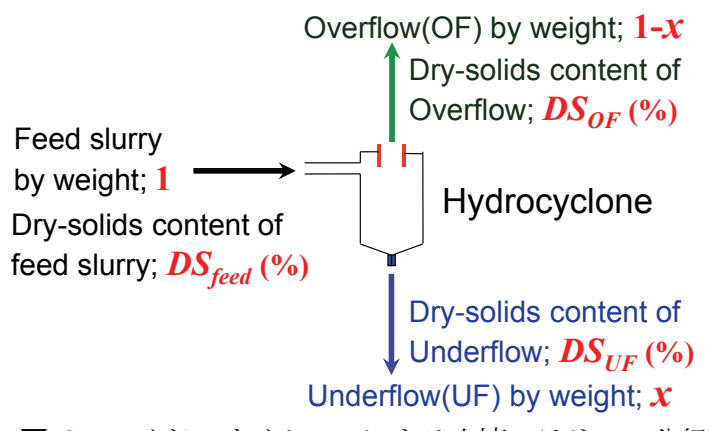

図-2 ハイドロサイクロンによる土壌スラリーの分級 
特性を持たない界面活性剤であり，水中に安定な気泡を 多数発生させる. 今回は, 捕収剂にカチオン系のアクリ ルアミン塩, アニオン系の脂肪酸塩やアルキル硫酸塩を, 気泡剤にMIBC, pine oil，2-ethyl-1-hexanolを，pH調整剤に 硫酸と水酸化ナトリウムをそれぞれ適宜使用した.

\section{(4) 軽質分の分離試験}

植物片などの軽質分を多く含む粗粒子分を入れた容器 一水を加えて摚找し軽質分を浮遊させながら，傾斜法 (decantation)によって軽質分を分離した。これにより，植 物片などの軽質分が保持している含有放射能量と軽質分 の除去による含有放射能量の低減効果の評価を行なった.

\section{4. 実験結果と考察}

\section{（1）放射性Cs污染土壤の含有放射能量と強熱減量}

表-1に運動場土壌(soil-PG) と住宅地等の除染除去土壌 (soil-RA)の元土壌(feed soil)の含有放射能量と強熱減量の 分析值を示寸. Soil-PGの含有放射能量は最小 $1,890 \mathrm{~Bq} / \mathrm{kg}$, 最大 $69,500 \mathrm{~Bq} k \mathrm{~kg}$ であり，11試料中5試料は21,000〜 46,300 Bq $\mathrm{kg}$ であった. 強熱減量は1.6 3.8\%であり，11試料中9 試料は1.6〜2.3\%であった．一方，soil-RAの含有放射能量 は最小 $8,790 \mathrm{~Bq} / \mathrm{kg}$ ，最大 $53,100 \mathrm{~Bq} / \mathrm{kg}$ であり，10試料中7試 料は $13,200 \sim 26,300 \mathrm{~Bq} / \mathrm{kg}$ であった. 強熱減量は8.5〜20.9\% であり 11試料中6試料は10.9〜 16.9\%であった. Soil-RAの 強熱減量は， soil-PGに比べてかなり高い值であった.

\section{(2) 放射性Cs污染土蚺の粒度分布}

Soil-PGとSoil-RAの粒度分布と単純平均化した粒度分布 を図-4(a), (b)に示寸．Soil-PGの粒度分布は比較的バラツ

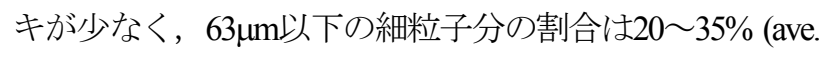
26.0\%)であった. Soil-PGは, 細粒子分の割合が比較的小 さいため, 土壎洗浄に適した粒度構成であると判断され た. Soil-RAの粒度分布は, soil-PGに比べてバラツキが大

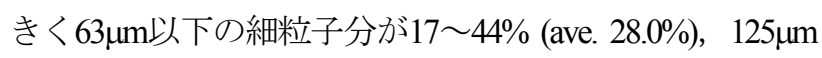

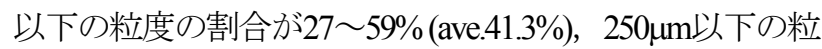
度の割合が36〜 68\% (ave. 51.0\%)であった. Soil-RAには, 細粒子分の割合が小さく高い減容化効果が望める粒度構 成の土壤(soil-RA-a, b, e, g, hの5試料)と細粒子分の割合が大 きく高い減容化効果が望みにくい粒度構成の土壌(soilRA-c, fの2試料)の両方が含まれていた.

\section{（3）土壌洗浄試験結果と放射性Cs量の収支}

表-1に示した計14試料について土壌洗浄試験を行ない, 各プロセスにおける土壤と含有放射能量の分離・除去過 程を調べた上で，土壌量と放射性Cs量の収支を求めた。

表-1 元土壤の含有放射能量, 強熱減量, および実験項目

\begin{tabular}{|c|c|c|c|c|c|c|}
\hline $\begin{array}{c}\text { Soil } \\
\text { samples }\end{array}$ & $\begin{array}{c}\text { Cs-Total } \\
(\mathrm{Bq} / \mathrm{kg})\end{array}$ & $\begin{array}{c}\text { Ignition } \\
\text { Loss } \\
(\%)\end{array}$ & $\begin{array}{c}\text { Grain size } \\
\text { distribution } \\
\text { test }\end{array}$ & $\begin{array}{c}\text { Soil } \\
\text { washing } \\
\text { test }\end{array}$ & $\begin{array}{c}\text { Mass } \\
\text { balance } \\
\text { analysis }\end{array}$ & $\begin{array}{c}\text { Light } \\
\text { fraction } \\
\text { separation }\end{array}$ \\
\hline \multicolumn{7}{|c|}{ (A) Playground (PG) } \\
\hline Soil-PG-a & 7,230 & $3.8 \%$ & $x$ & $x$ & $x$ & --- \\
\hline Soil-PG-b & 46,300 & $1.8 \%$ & $x$ & $x$ & $x$ & --- \\
\hline Soil-PG-C & 40,900 & $2.2 \%$ & $x$ & $\mathrm{x}$ & $x$ & --- \\
\hline Soil-PG-d & 69,500 & $2.9 \%$ & $x$ & $x$ & $x$ & --- \\
\hline Soil-PG-e & 32,700 & $2.3 \%$ & $x$ & $x$ & $x$ & --- \\
\hline Soil-PG-f & 5,640 & $2.1 \%$ & $x$ & $x$ & $x$ & --- \\
\hline Soil-PG-g & 1,890 & $2.1 \%$ & $x$ & --- & --- & --- \\
\hline Soil-PG-h & 7,610 & $1.9 \%$ & $x$ & --- & --- & --- \\
\hline Soil-PG-i & 62,300 & $1.9 \%$ & $x$ & -- & --- & --- \\
\hline Soil-PG-j & 21,000 & $1.6 \%$ & $x$ & $x$ & $x$ & --- \\
\hline Soil-PG-k & 23,600 & $1.6 \%$ & --- & $x$ & $x$ & --- \\
\hline \multicolumn{7}{|c|}{ (B) Residential area (RA) } \\
\hline Soil-RA-a & 26,300 & $8.8 \%$ & $x$ & $x$ & $x$ & $x$ \\
\hline Soil-RA-b & 15,800 & $11.2 \%$ & $x$ & $x$ & $x$ & $x$ \\
\hline Soil-RA-C & 18,900 & $16.9 \%$ & $x$ & $x$ & $x$ & $x$ \\
\hline Soil-RA-d & 18,800 & $8.9 \%$ & --- & $x$ & $x$ & $x$ \\
\hline Soil-RA-e & 13,200 & $8.5 \%$ & $x$ & $x$ & $x$ & $x$ \\
\hline Soil-RA-f & 51,100 & $20.9 \%$ & $x$ & -- & --- & $x$ \\
\hline Soil-RA-g & 24,000 & $13.7 \%$ & $x$ & -- & --- & --- \\
\hline Soil-RA-h & 53,100 & $14.8 \%$ & $x$ & --- & --- & $x$ \\
\hline Soil-RA-i & 15,700 & $15.8 \%$ & --- & $x$ & --- & --- \\
\hline Soil-RA-j & 8,790 & $10.9 \%$ & --- & --- & --- & --- \\
\hline
\end{tabular}

Key: X, tested; ----, untested

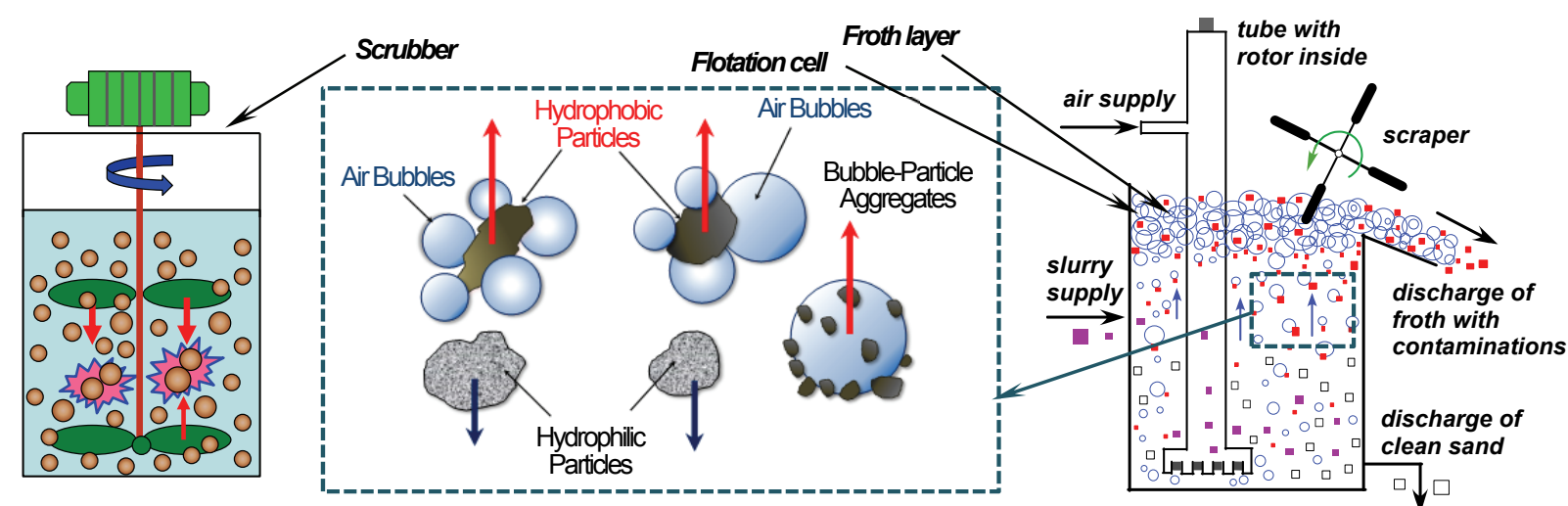

(A) Scrubbing, detachment of contaminated small particles
(B) Selectively hydrophobizing contaminated particles by collectors, attachment to arr bubbles, nsing to the surtace, and formation of froth layer

図-3 スクラビング・フローテーションの原理と概要 


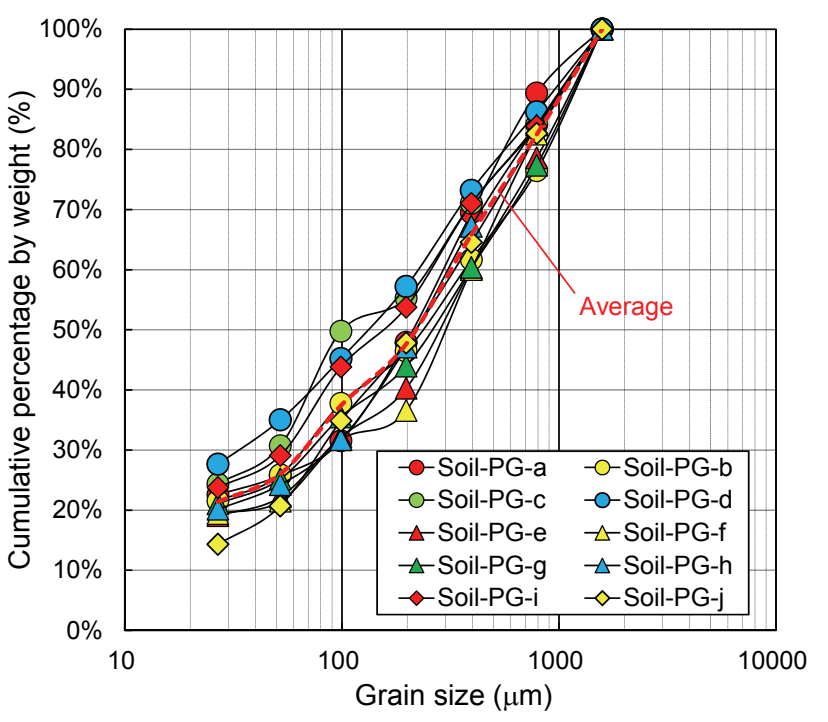

(a) Playground (PG)

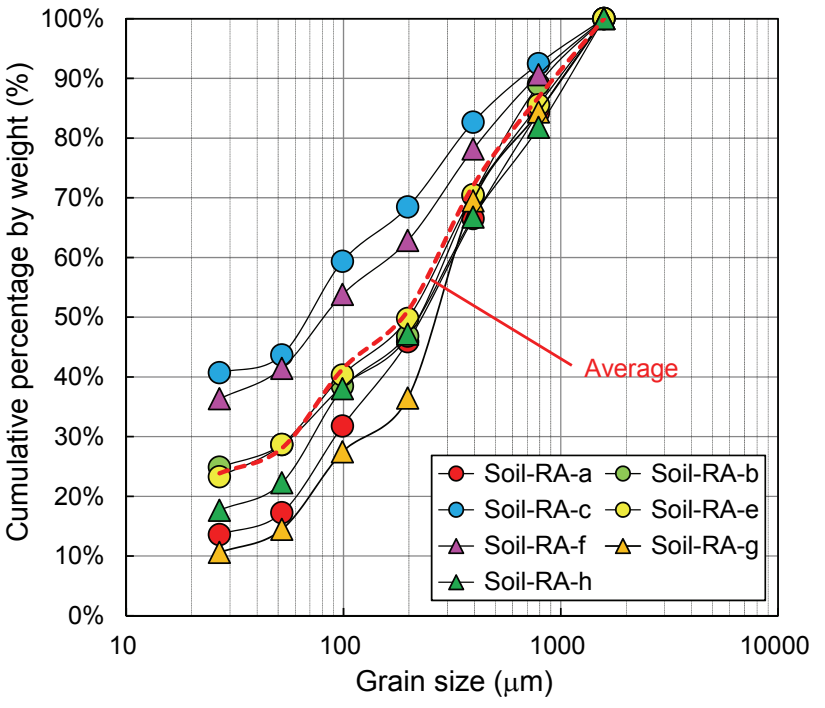

(b) Residential area (RA)

図-4 $2 \mathrm{~mm}$ 以下の土壌(feed $<2 \mathrm{~mm})$ の粒度分布（累積加積曲線）

なお，サイクロンOFを主体とする洗浄排水の凝集沈殿 処理水の放射性Cs濃度は，全て定量下限值未満( $<10$ $\mathrm{Bq} / \mathrm{kg}$ )であった，放射性Cs量の収支は土壌粒子(有機物を 含む)のみに着目すれば良い。洗浄試験で使用した薬剤 (捕収剂，凝集剂など)の添加量は土壌量に比べて僅かで あるため，収支計算において薬剤量は無視している，洗 浄試験結果と放射性Cs量の収支計算の例を図-5に示す. 含有放射能量は有効数字3枌の值で表示した. 収支計算 の途中では丸めずに最終的な総計において3桁に丸めた. 計算途中すなわち各プロセスでの放射性 $\mathrm{Cs}$ 量 $(\mathrm{Bq}) の$ 計算 では，2桁多い5桁まで残しそれ以降の数字は切り捨てた.

図-5(A)に示したsoil-PG-kの例では，乾燥重量表記で $23,600 \mathrm{~Bq} / \mathrm{kg}$ の元土畩100 kgから1,600 Bq/kgの洗浄土72.9 kg と2,090 Bqkgの2〜4mm粗粒子分 $10.7 \mathrm{~kg}$ が産出され，濃縮 残椬16.4 kg (138,000 Bq/kgのOF $15.2 \mathrm{~kg}, 78,600 \mathrm{~Bq} / \mathrm{kg}$ のフロ ス $1.2 \mathrm{~kg}$ )が発生した，放射性Cs量の収支については，2段 湿式フルイが $86.8 \%$, ハイドロサイクロンが $116.8 \%$, フロ ーテーションが78.0\%であった。元土壌の放射性Cs量 2,360,000 Bqを $100 \%$ とした場合，洗浄土は $4.9 \%$, 粗粒子分 は0.9\%, 濃縮残椬は92.9\% (OF: 88.9\%, フロス: 4.0\%)を占め, プロセス全体の収支は $98.7 \%$ となった。濃縮残椬の発生 率は16.4\%であるが，放射性Csの約 $93 \%$ \%濃縮残椬に集 約されることがわかった. 産出された 2 4mm粗粒子分, 洗浄土, $\mathrm{OF}$, およびフロスの放射性Cs量の合計 $2,330,000 \mathrm{~Bq}$ を $100 \%$ とした場合には，洗浄土は $5.0 \%$, 粗粒子分は $1.0 \%$, 濃縮残椬は94.0\%(OF: 90.0\%, フロス: 4.0\%)の割合となった。

図-5(B)に示したsoil-RA-dの例では， $18,800 \mathrm{~Bq} / \mathrm{kg}$ の元土 壤100 kgから2,840 Bq/kgの洗浄土53.2 kg と 13,400 Bq/kgの2 〜 4mm 粗粒子分 $14.0 \mathrm{~kg}, 2,710 \mathrm{~Bq} / \mathrm{kg}$ の $\sim 40 \mathrm{~mm}$ 粗粒子分 $13.0 \mathrm{~kg}$ が産出され，濃縮残椬 $19.8 \mathrm{~kg}(74,600 \mathrm{~Bq} / \mathrm{kg}$ のF 14.6 $\mathrm{kg}, 17,500 \mathrm{~Bq} / \mathrm{kg}$ のフロス5.2 kg)が発生した．放射性Cs量の 収支については，2段湿式フルイが $92.2 \%$, ハイドロサイ クロンが $93.5 \%$, フローテーションが $74.8 \%$ であった。元 土壌の放射性Cs量1,880,000 Bqを100\%とした場合，洗浄 土は $8.0 \%, 4 \sim 40 \mathrm{~mm}$ 粗粒子分は $1.9 \%, 2 ４ \mathrm{~mm}$ 粗粒子分は $10.0 \%$, 濃縮残椬は $62.7 \%(\mathrm{OF}: 57.9 \%$, フロス: $4.8 \%)$ を占め, プロセス全体の収支は $82.4 \%$ となった。 また，産出され た粗粒子分, 洗浄土, $\mathrm{OF}$, およびフロスの放射性Cs量の合 計 $1,550,000 \mathrm{~Bq} 100 \%$ とした場合には，洗浄土は9.7\%,4 $40 \mathrm{~mm}$ 粗粒子分は $2.3 \%, 2 ４ \mathrm{~mm}$ 粗粒子分は $12.1 \%$, 濃縮残 椬は76.2\%(OF: 70.3\%, フロス: 5.9\%)の割合となった.

8 試料のsoil-PGの洗浄試験結果と放射性Cs量の収支を 表-2に，6試料のsoil-RAの試験結果と収支を表-3に示す. 試料名称の横に使用した捕収剤の種類を記載した。 図-5 と同じく表-2, 表-3 においても元土壤量を $100 \mathrm{~kg}$ として， 各プロセスの土壌量 $(\mathrm{kg})$, 含有放射能量 $(\mathrm{Bq} / \mathrm{kg})$, これらの 積である放射性 $\mathrm{Cs}$ 量(Bq)について, 投入量(input), 産出量 (output), および中間体(intermediate)の值をそれぞれ記した. 本実験の収支の結果を以下に要約する。

1） 2段湿式フルイの収支は，soil-PGでは8試料全てが81.2 〜 105.8\% (ave. 92.0\%) と良好な值であった. Soil-RAで は5試料中3試料が $80.5 〜 113.7 \%$ と良好な值であつたが， 2 試料が $60 \%$ 台の值であった。

2) ハイドロサイクロンの収支は，soil-PGでは8試料全て が78.5〜 124.7\% (ave. 104.3\%) と概ね良好な值であった。 Soil-RA では soil-RA-e (68.0\%)を除く4 試料が $88.0 〜$ 105.2\% (ave. 96.6\%)と良好な值であった。

3) スクラビング・フローテーションの収支は， soil-PG ではsoil-PG-c (49.6\%)を除く7試料が65.2〜95.9\% (ave. 77.9\%)であり, soil-RAの5試料は62.5～96.3\%(ave. 79.0\%) 
Untreated feed soil (Input), soil-PG-k \begin{tabular}{c|l}
$100.0 \mathrm{~kg}$-dry & $2,360,000 \mathrm{~Bq}$ \\
\hline
\end{tabular} \begin{tabular}{l|l}
\hline $23,600 \mathrm{~Bq} / \mathrm{kg}$ & $100.0 \%$ \\
\hline
\end{tabular}

(a) Scr

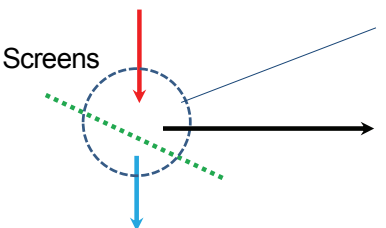

$86.8 \%$

Coarse fraction, $2 \sim 4 \mathrm{~mm}$ (Output) \begin{tabular}{r|r}
10.7 kg-dry & $22,363 \mathrm{~Bq}$ \\
\hline
\end{tabular}

Feed $<2 \mathrm{~mm}$ (Intermediate)

89.3 kg-dry $2,027,100 \mathrm{~Bq}$ \begin{tabular}{l|l|l}
$22,700 \mathrm{~Bq} / \mathrm{kg}$ & $85.9 \%$ \\
\hline
\end{tabular}

(b) Hydrocyclone

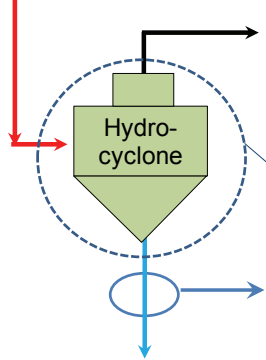

Overflow (Output)

\begin{tabular}{l|lll|l} 
(b) Hydro- \\
cyclone
\end{tabular}

(A) Soil-PG-k
Untreated feed soil (Input), soil-RA-d

\begin{tabular}{r|l}
\hline $100.0 \mathrm{~kg}$-dry & $1,880,000 \mathrm{~Bq}$ \\
\hline
\end{tabular}

\begin{tabular}{ll}
$18,800 \mathrm{~Bq} / \mathrm{kg}$ & $100.0 \%$ \\
\hline
\end{tabular}

(a)

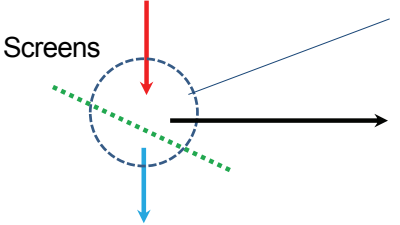

Feed $<2 \mathrm{~mm}$ (Intermediate)

\begin{tabular}{r|c}
\hline $73.0 \mathrm{~kg}$-dry & $1,511,100 \mathrm{~Bq}$ \\
\hline $20,700 \mathrm{~Bq} / \mathrm{kg}$ & $80.4 \%$
\end{tabular}

Balance-1, screens $\underline{92.2 \%}$

Coarse fraction, $2 \sim 4 \mathrm{~mm}$ (Output)

\begin{tabular}{r|r}
$14.0 \mathrm{~kg}$-dry & $187,600 \mathrm{~Bq}$
\end{tabular}

\begin{tabular}{l|l}
$13,400 \mathrm{~Bq} / \mathrm{kg}$ & $10.0 \%$ \\
\hline
\end{tabular}

Coarse fraction, 4 40mm (Output)

$13.0 \mathrm{~kg}$-dry $35,230 \mathrm{~Bq}$

\begin{tabular}{l|l}
$2,710 \mathrm{~Bq} / \mathrm{kg}$ & $1.9 \%$ \\
\hline
\end{tabular}

(b) Hydrocyclone

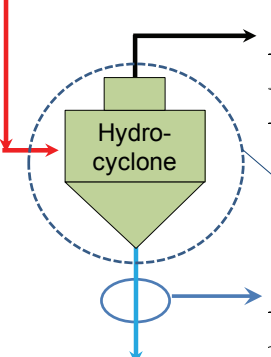

Overflow (Output) $14.6 \mathrm{~kg}$-dry $1,089,100 \mathrm{~Bq}$ \begin{tabular}{l|l}
$74,600 \mathrm{~Bq} / \mathrm{kg}$ & $57.9 \%$ \\
\hline
\end{tabular}

Balance-2, cyclone 93.5\%

(c) Scrubbing-

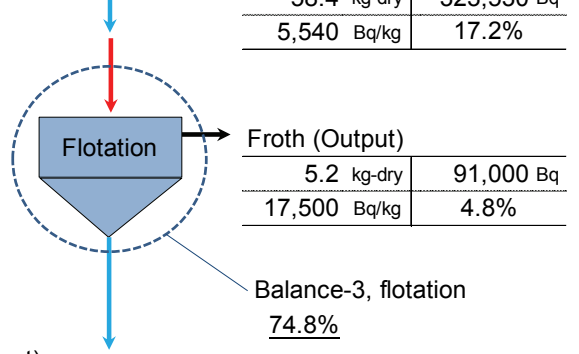

Clean sand (Output) flotation

\begin{tabular}{|c|c|c|c|c|c|c|}
\hline 53.2 kg-dry & \multicolumn{2}{|c|}{$151,080 \mathrm{~Bq}$} & & & & \\
\hline $2,840 \mathrm{~Bq} / \mathrm{kg}$ & \multicolumn{2}{|l|}{$8.0 \%$} & & & & \\
\hline \multicolumn{7}{|c|}{ Total balance, soil-RA-d (Anion) } \\
\hline Feed soil (input) & $100.0 \mathrm{~kg}$ & 18,800 & $\mathrm{~Bq} / \mathrm{kg}$ & $1,880,000 \mathrm{~Bq}$ & $100.0 \%$ & ---- \\
\hline Coarse $+4 \mathrm{~mm}$ & $13.0 \mathrm{~kg}$ & 2,710 & $\mathrm{~Bq} / \mathrm{kg}$ & $35,230 \mathrm{~Bq}$ & $1.9 \%$ & $2.3 \%$ \\
\hline Coarse $+2 \mathrm{~mm}$ & $14.0 \mathrm{~kg}$ & 13,400 & $\mathrm{~Bq} / \mathrm{kg}$ & $187,600 \mathrm{~Bq}$ & $10.0 \%$ & $12.1 \%$ \\
\hline Clean sand & $53.2 \mathrm{~kg}$ & 2,840 & $\mathrm{~Bq} / \mathrm{kg}$ & $151,080 \mathrm{~Bq}$ & $8.0 \%$ & $9.7 \%$ \\
\hline Overflow & $14.6 \mathrm{~kg}$ & 74,600 & $\mathrm{~Bq} / \mathrm{kg}$ & $1,089,100 \mathrm{~Bq}$ & $57.9 \%$ & $70.3 \%$ \\
\hline Froth & $5.2 \mathrm{~kg}$ & 17,500 & $\mathrm{~Bq} / \mathrm{kg}$ & $91,000 \mathrm{~Bq}$ & $4.8 \%$ & $5.9 \%$ \\
\hline Total (output) & $100.0 \mathrm{~kg}$ & & & $1,550,000 \mathrm{~Bq}$ & $82.4 \%$ & $100.0 \%$ \\
\hline
\end{tabular}

(B) Soil-RA-d

図-5 土壌洗浄試験結果と放射性Cs量(Bq)の収支計算の例

であった。

スクラビング・フローテーションの放射性Cs量(Bq)の 収支の值が 2段湿式フルイやハイドロサイクロンのそれ らに比べて低い理由としては，以下の事柄が考えられる.

- 洗浄土量は，試験に供したサイクロンUF量から掻き 取ったフロス量を差し引くことで求めた。洗浄土は 試験後に脱水操作(水切り)を行なってから回収した.

- スクラビング・フローテーション後の洗浄土に微細 な粒子分が残存している場合には，これらの一部が 脱水操作の際に水と一緒に流出した可能性がある.

これらの微細な粒子分の含有放射能量が高いほど，ス クラビング・フローテーションの放射性Cs量の収支は相 対的に低下する. 土壌洗浄の実プラントにおいても，こ のような微細な粒子分は脱水フルイ(dewatering screen)に
おいて水と一緒に流出しやすい. 図一1に示したように脱 水フルイから流出した細粒子分は，オーバーフロー(OF) やフロスと一緒に凝集沈殿と脱水工程(press)を経て濃縮 残椬となる. すなわち, 流出分だけ洗浄土の産出量が減 少し, 濃縮残椬の発生量は増加することになる.

\section{(4) 土壤洗浄による浄化・減容化効果の評価}

洗浄試験を行なった 14 試料の元土壤とサイクロンUF, 洗浄土の含有放射能量の関係を図-6(A)に，元土壌と2段 湿式フルイによる分級後の粗粒子分(coarse fractions)の含 有放射能量の関係を図-6(B)に示す。図中には，(a)含有 放射能量の除去率を表す線，および(b)浄化の目標值(目 安)として3,000 Bq $\mathrm{kg}$ と $8,000 \mathrm{~Bq} / \mathrm{kg}$ の線を示した.

図一6(A)に示したように，soil-PGの含有放射能量除去率 
表-2 運動場土壌(soil-PG)の土壤洗浄試験結果と放射性Cs量(Bq)の収支

\begin{tabular}{|c|c|c|c|c|c|c|c|c|c|c|c|c|}
\hline \multirow[b]{2}{*}{ Stream (input / output) } & \multicolumn{3}{|c|}{ Soil-PG-a (Anion) } & \multicolumn{3}{|c|}{ Soil-PG-b (Anion) } & \multicolumn{3}{|c|}{ Soil-PG-C (Anion) } & \multicolumn{3}{|c|}{ Soil-PG-d (Anion) } \\
\hline & \begin{tabular}{|c|} 
Dry solids \\
(A) \\
(kg)
\end{tabular} & $\begin{array}{c}\text { Cs-total } \\
(\mathrm{B}) \\
(\mathrm{Bq} / \mathrm{kg})\end{array}$ & $\begin{array}{c}\mathrm{Bq} \\
(=\mathrm{A} \times \mathrm{B}) \\
(\mathrm{Bq})\end{array}$ & $\begin{array}{c}\text { Dry solids } \\
\text { (A) } \\
\text { (kg) }\end{array}$ & $\begin{array}{l}\text { Cs-total } \\
\text { (B) } \\
(\mathrm{Bq} / \mathrm{kg})\end{array}$ & $\begin{array}{c}\mathrm{Bq} \\
(=\mathrm{A} \times \mathrm{B}) \\
(\mathrm{Bq})\end{array}$ & $\begin{array}{c}\text { Dry solids } \\
\text { (A) } \\
\text { (kg) }\end{array}$ & $\begin{array}{l}\text { Cs-total } \\
\text { (B) } \\
(\mathrm{Bq} / \mathrm{kg})\end{array}$ & $\begin{array}{c}\mathrm{Bq} \\
(=\mathrm{A} \times \mathrm{B}) \\
(\mathrm{Bq})\end{array}$ & \begin{tabular}{|c} 
Dry solids \\
(A) \\
(kg)
\end{tabular} & $\begin{array}{l}\text { Cs-total } \\
\text { (B) } \\
(\mathrm{Bq} / \mathrm{kg})\end{array}$ & $\begin{array}{c}\mathrm{Bq} \\
(=\mathrm{A} \times \mathrm{B}) \\
(\mathrm{Bq})\end{array}$ \\
\hline Untreated feed soil (input) & 100.0 & 7,230 & 723,000 & 100.0 & 46,300 & $4,630,000$ & 100.0 & 40,900 & $4,090,000$ & 100.0 & 69,500 & $6,950,000$ \\
\hline Coarse, $+2-4 \mathrm{~mm}$ (output) & 9.2 & 920 & 8,464 & 22.8 & 4,270 & 97,356 & 14.5 & 1,950 & 28,275 & 7.8 & 1,440 & 11,232 \\
\hline Feed $<2 \mathrm{~mm}$ (intermediate) & 90.8 & 8,010 & 727,300 & 77.2 & 49,400 & $3,813,600$ & 85.5 & 43,600 & $3,727,800$ & 92.2 & 74,300 & $6,850,400$ \\
\hline Subtotal-1, screens & 100.0 & --- & 735,760 & 100.0 & --- & $3,910,900$ & 100.0 & --- & $3,756,000$ & 100.0 & --- & $6,861,600$ \\
\hline Balance- 1 , screens & $100.0 \%$ & --- & $101.8 \%$ & $100.0 \%$ & -- & $84.5 \%$ & $100.0 \%$ & --- & $91.8 \%$ & $100.0 \%$ & -- & $98.7 \%$ \\
\hline Feed $<2 \mathrm{~mm}$ (intermediate) & 90.8 & 8,010 & 727,300 & 77.2 & 49,400 & $3,813,600$ & 85.5 & 43,600 & $3,727,800$ & 92.2 & 74,300 & $6,850,400$ \\
\hline Underflow (intermediate) & 71.7 & 1,710 & 122,600 & 60.6 & 15,700 & 951,420 & 63.4 & 9,520 & 603,560 & 61.6 & 29,200 & $1,798,700$ \\
\hline Overflow (output) & 19.1 & 27,700 & 529,070 & 16.6 & 196,000 & $3,253,600$ & 22.1 & 183,000 & $4,044,300$ & 30.6 & 209,000 & $6,395,400$ \\
\hline Subtotal-2, hydrocyclone & 90.8 & --- & 651,670 & 77.2 & --- & $4,205,000$ & 85.5 & --- & $4,647,800$ & 92.2 & --- & $8,194,100$ \\
\hline Balance-2, hydrocyclone & $100.0 \%$ & -- & $89.6 \%$ & $100.0 \%$ & -- & $110.3 \%$ & $100.0 \%$ & --- & $124.7 \%$ & $100.0 \%$ & -- & $119.6 \%$ \\
\hline Underflow (intermediate) & 71.7 & 1,710 & 122,600 & 60.6 & 15,700 & 951,420 & 63.4 & 9,520 & 603,560 & 61.6 & 29,200 & $1,798,700$ \\
\hline Clean sand (output) & 67.3 & 810 & 54,510 & 57.6 & 6,750 & 388,800 & 59.7 & 3,290 & 196,410 & 56.4 & 12,090 & 681,870 \\
\hline Froth (output) & 4.4 & 6,160 & 27,100 & 3.0 & 95,400 & 286,200 & 3.7 & 27,800 & 102,860 & 5.2 & 94,400 & 490,880 \\
\hline Subtotal-3, scrubbing-flotation & 71.7 & --- & 81,610 & 60.6 & --- & 675,000 & 63.4 & --- & 299,270 & 61.6 & --- & $1,172,700$ \\
\hline Balance-3, scrubbing-flotation & $100.0 \%$ & --- & $66.6 \%$ & $100.0 \%$ & --- & $70.9 \%$ & $100.0 \%$ & -- & $49.6 \%$ & $100.0 \%$ & --- & $65.2 \%$ \\
\hline Total output & 100.0 & --- & 619,000 & 100.0 & --- & $4,030,000$ & 100.0 & --- & $4,370,000$ & 100.0 & --- & $7,580,000$ \\
\hline Balance & $100.0 \%$ & -- & $85.6 \%$ & $100.0 \%$ & --- & $87.0 \%$ & $100.0 \%$ & --- & $106.8 \%$ & $100.0 \%$ & --- & $109.1 \%$ \\
\hline Clean products (calculated value) & 76.5 & 824 & 63,000 & 80.4 & 6,040 & 486,000 & 74.2 & 3,030 & 225,000 & 64.2 & 10,800 & 693,000 \\
\hline Sludge cake (calculated value) & 23.5 & 23,700 & 556,000 & 19.6 & 181,000 & $3,540,000$ & 25.8 & 161,000 & $4,150,000$ & 35.8 & 192,000 & $6,890,000$ \\
\hline Clean products (clean sand+coarse) & $76.5 \%$ & --- & $10.2 \%$ & $80.4 \%$ & --- & $12.1 \%$ & $74.2 \%$ & --- & $5.1 \%$ & $64.2 \%$ & --- & $9.1 \%$ \\
\hline Sludge cake (overflow+froth) & $23.5 \%$ & --- & $89.8 \%$ & $19.6 \%$ & -- & $87.9 \%$ & $25.8 \%$ & -- & $94.9 \%$ & $35.8 \%$ & -- & $90.9 \%$ \\
\hline
\end{tabular}

\begin{tabular}{|c|c|c|c|c|c|c|c|c|c|c|c|c|}
\hline \multirow[b]{2}{*}{ Stream (input / output) } & \multicolumn{3}{|c|}{ Soil-PG-e (Anion+Cation) } & \multicolumn{3}{|c|}{ Soil-PG-f (Anion) } & \multicolumn{3}{|c|}{ Soil-PG-j (Anion) } & \multicolumn{3}{|c|}{ Soil-PG-k (Cation) } \\
\hline & \begin{tabular}{|c} 
Dry solids \\
(A) \\
$(\mathrm{kg})$ \\
\end{tabular} & $\begin{array}{c}\text { Cs-total } \\
(\mathrm{B}) \\
(\mathrm{Bq} / \mathrm{kg}) \\
\end{array}$ & $\begin{array}{c}\mathrm{Bq} \\
(=\mathrm{A} \times \mathrm{B}) \\
(\mathrm{Bq})\end{array}$ & \begin{tabular}{|c|} 
Dry solids \\
(A) \\
(kg)
\end{tabular} & $\begin{array}{l}\text { Cs-total } \\
(\mathrm{B}) \\
(\mathrm{Bq} / \mathrm{kg}) \\
\end{array}$ & $\begin{array}{c}\mathrm{Bq} \\
(=\mathrm{A} \times \mathrm{B}) \\
(\mathrm{Bq})\end{array}$ & \begin{tabular}{|c|} 
Dry solids \\
(A) \\
$(\mathrm{kg})$
\end{tabular} & $\begin{array}{l}\text { Cs-total } \\
(\mathrm{B}) \\
(\mathrm{Bq} / \mathrm{kg}) \\
\end{array}$ & $\begin{array}{c}\mathrm{Bq} \\
(=\mathrm{A} \times \mathrm{B}) \\
(\mathrm{Bq})\end{array}$ & \begin{tabular}{|c} 
Dry solids \\
(A) \\
(kg)
\end{tabular} & $\begin{array}{l}\text { Cs-total } \\
(\mathrm{B}) \\
(\mathrm{Bq} / \mathrm{kg})\end{array}$ & $\begin{array}{c}\mathrm{Bq} \\
(=\mathrm{A} \times \mathrm{B}) \\
(\mathrm{Bq})\end{array}$ \\
\hline Untreated feed soil (input) & 100.0 & 32,700 & $3,270,000$ & 100.0 & 5,640 & 564,000 & 100.0 & 21,000 & $2,100,000$ & 100.0 & 23,600 & $2,360,000$ \\
\hline Coarse, $+2-4 \mathrm{~mm}$ (output) & 20.9 & 12,400 & 259,160 & 7.5 & 1,720 & 12,900 & 10.5 & 3,100 & 32,550 & 10.7 & 2,090 & 22,363 \\
\hline Feed <2mm (intermediate) & 79.1 & 32,100 & $2,539,100$ & 92.5 & 6,310 & 583,670 & 89.5 & 18,700 & $1,673,600$ & 89.3 & 22,700 & $2,027,100$ \\
\hline Subtotal-1, screens & 100.0 & --- & $2,798,200$ & 100.0 & --- & 596,570 & 100.0 & --- & $1,706,100$ & 100.0 & --- & $2,049,400$ \\
\hline Balance- 1 , screens & $100.0 \%$ & --- & $85.6 \%$ & $100.0 \%$ & --- & $105.8 \%$ & $100.0 \%$ & --- & $81.2 \%$ & $100.0 \%$ & --- & $86.8 \%$ \\
\hline Feed $<2 \mathrm{~mm}$ (intermediate) & 79.1 & 32,100 & $2,539,100$ & 92.5 & 6,310 & 583,670 & 89.5 & 18,700 & $1,673,600$ & 89.3 & 22,700 & $2,027,100$ \\
\hline Underflow (intermediate) & 63.4 & 10,100 & 640,340 & 75.8 & 1,880 & 142,500 & 73.5 & 2,700 & 198,450 & 74.1 & 3,650 & 270,460 \\
\hline Overflow (output) & 15.7 & 106,000 & $1,664,200$ & 16.7 & 18,900 & 315,630 & 16.0 & 96,600 & $1,545,600$ & 15.2 & 138,000 & $2,097,600$ \\
\hline Subtotal-2, hydrocyclone & 79.1 & --- & $2,304,500$ & 92.5 & --- & 458,130 & 89.5 & --- & $1,744,000$ & 89.3 & --- & $2,368,000$ \\
\hline Balance-2, hydrocyclone & $100.0 \%$ & --- & $90.8 \%$ & $100.0 \%$ & --- & $78.5 \%$ & $100.0 \%$ & --- & $104.2 \%$ & $100.0 \%$ & --- & $116.8 \%$ \\
\hline Underflow (intermediate) & 63.4 & 10,100 & 640,340 & 75.8 & 1,880 & 142,500 & 73.5 & 2,700 & 198,450 & 74.1 & 3,650 & 270,460 \\
\hline Clean sand (output) & 60.6 & 6,650 & 402,990 & 69.7 & 1,150 & 80,155 & 70.5 & 1,960 & 138,180 & 72.9 & 1,600 & 116,640 \\
\hline Froth (output) & 2.8 & 42,700 & 119,560 & 6.1 & 7,160 & 43,676 & 3.0 & 17,400 & 52,200 & 1.2 & 78,600 & 94,320 \\
\hline Subtotal-3, scrubbing-flotation & 63.4 & --- & 522,550 & 75.8 & --- & 123,830 & 73.5 & --- & 190,380 & 74.1 & --- & 210,960 \\
\hline Balance-3, scrubbing-flotation & $100.0 \%$ & --- & $81.6 \%$ & $100.0 \%$ & --- & $86.9 \%$ & $100.0 \%$ & --- & $95.9 \%$ & $100.0 \%$ & --- & $78.0 \%$ \\
\hline Total output & 100.0 & --- & $2,440,000$ & 100.0 & --- & 452,000 & 100.0 & --- & $1,760,000$ & 100.0 & --- & $2,330,000$ \\
\hline Balance & $100.0 \%$ & --- & $74.6 \%$ & $100.0 \%$ & --- & $80.1 \%$ & $100.0 \%$ & --- & $83.8 \%$ & $100.0 \%$ & --- & $98.7 \%$ \\
\hline Clean products (calculated value) & 81.5 & 8,120 & 662,000 & 77.2 & 1,210 & 93,100 & 81.0 & 2,110 & 171,000 & 83.6 & 1,660 & 139,000 \\
\hline Sludge cake (calculated value) & 18.5 & 96,200 & $1,780,000$ & 22.8 & 15,700 & 359,000 & 19.0 & 84,200 & $1,600,000$ & 16.4 & 134,000 & $2,190,000$ \\
\hline Clean products (clean sand+coarse) & $81.5 \%$ & --- & $27.1 \%$ & $77.2 \%$ & --- & $20.6 \%$ & $81.0 \%$ & --- & $9.7 \%$ & $83.6 \%$ & --- & $6.0 \%$ \\
\hline Sludge cake (overflow+froth) & $18.5 \%$ & -- & $72.9 \%$ & $22.8 \%$ & --- & $79.4 \%$ & $19.0 \%$ & --- & $90.3 \%$ & $16.4 \%$ & --- & $94.0 \%$ \\
\hline
\end{tabular}

Balance of radio-Cs $(\mathrm{Bq}) ; \quad \square: 80 \sim 120 \%$

$: 60 \sim 80 \%$ or $120 \sim 140 \%$

: under $60 \%$

は, UFが58.0〜 87.2\% (ave. 73.1\%)，洗浄土が79.6〜 93.2\% (ave. 86.5\%)であり， soil-RAの除去率は，UFが50.4〜 78.1\% (ave. 68.7\%), 洗浄土が72.2〜92.6\% (ave. 84.0\%)であった.

サイクロンによる分級処理は，除去率のバラツキが大 きい上に平均的な除去率は70\%前後に止まった．スクラ ビング・フローテーションによる化学的な洗浄処理を追 加することによって，除去率のバラツキは小さくなり， 平均的な除去率は $84 \sim 87 \%$ 一と大幅に改善された. 筆者 らの検討では，soil-PGと soil-RAの両方において細砂〜砂 分の表面に金雲母(phlogopite)や蛭石(vermiculite)などが付 着, もしくは砂表面の一部を有機物や酸化水酸化鉄が覆 っていることが推察された ${ }^{20}$. これらの物質はCsを吸着
しやすいことが知られている21). 薬剤を用いたスクラビ ングによって，Csを吸着している金雲母や蛭石，有機物， 酸化水酸化鉄などを砂表面から効果的に剥離すること, 続くフローテーションにおいて, これらのCs吸着粒子が フロスとして系外一除去されることが放射性Csの低減に 大きく寄与したものと考えられた．また，洗浄土の目標 を3,000 Bqkg とした場合には, soil-PGおよびsoil-RAの両 方において20,000〜30,000 Bq kgまでが浄化可能であるこ と，目標を8,000 Bqkgとした場合には，soil-PGであれば 約 $50,000 \mathrm{~Bq} / \mathrm{kg}$ までが浄化可能であることがわかった.

続いて粗粒子分について検討する. 表-2に示したよう に, Soil-PGの2〜4mm粗粒子分の中では soil-PG-e だけが 
表-3 住宅地等の除染除去土壤(soil-RA)の土壌洗浄試験結果と放射性Cs量(Bq)の収支

\begin{tabular}{|c|c|c|c|c|c|c|c|c|c|}
\hline \multirow[b]{2}{*}{ Stream (input / output) } & \multicolumn{3}{|c|}{ Soil-RA-a (Anion+Cation) } & \multicolumn{3}{|c|}{ Soil-RA-b (Anion) } & \multicolumn{3}{|c|}{ Soil-RA-C (Anion+Cation) } \\
\hline & $\begin{array}{c}\text { Dry solids } \\
\text { (A) } \\
\text { (kg) }\end{array}$ & $\begin{array}{c}\text { Cs-total } \\
\text { (B) } \\
(\mathrm{Bq} / \mathrm{kg})\end{array}$ & $\begin{array}{c}\mathrm{Bq} \\
(=\mathrm{A} \times \mathrm{B}) \\
(\mathrm{Bq})\end{array}$ & \begin{tabular}{|c|} 
Dry solids \\
(A) \\
(kg)
\end{tabular} & $\begin{array}{c}\text { Cs-total } \\
\text { (B) } \\
(\mathrm{Bq} / \mathrm{kg})\end{array}$ & $\begin{array}{c}\mathrm{Bq} \\
(=\mathrm{A} \times \mathrm{B}) \\
(\mathrm{Bq})\end{array}$ & \begin{tabular}{|c|} 
Dry solids \\
(A) \\
(kg)
\end{tabular} & $\begin{array}{c}\text { Cs-total } \\
\text { (B) } \\
(\mathrm{Bq} / \mathrm{kg})\end{array}$ & $\begin{array}{c}\mathrm{Bq} \\
(=\mathrm{A} \times \mathrm{B}) \\
(\mathrm{Bq})\end{array}$ \\
\hline Untreated feed soil (input) & 100.0 & 26,300 & $2,630,000$ & 100.0 & 15,800 & $1,580,000$ & 100.0 & 18,900 & $1,890,000$ \\
\hline Coarse, $+4 \mathrm{~mm}$ (output) & 11.0 & 1,500 & 16,500 & 22.0 & 970 & 21,340 & 19.0 & 580 & 11,020 \\
\hline Coarse, $+2-4 \mathrm{~mm}$ (output) & 13.0 & 6,320 & 82,160 & 12.0 & 5,510 & 66,120 & 12.0 & 8,040 & 96,480 \\
\hline Feed <2mm (intermediate) & 76.0 & 20,700 & $1,573,200$ & 66.0 & 13,200 & 871,200 & 69.0 & 20,500 & $1,414,500$ \\
\hline Subtotal-1, screens & 100.0 & --- & $1,671,800$ & 100.0 & --- & 958,660 & 100.0 & --- & $1,522,000$ \\
\hline Balance- 1 , screens & $100.0 \%$ & --- & $63.6 \%$ & $100.0 \%$ & --- & $60.7 \%$ & $100.0 \%$ & --- & $80.5 \%$ \\
\hline Feed $<2 \mathrm{~mm}$ (intermediate) & 76.0 & 20,700 & $1,573,200$ & 66.0 & 13,200 & 871,200 & 69.0 & 20,500 & $1,414,500$ \\
\hline Underflow (intermediate) & 62.3 & 5,760 & 358,840 & 49.3 & 3,720 & 183,390 & 43.5 & 5,650 & 245,770 \\
\hline Overflow (output) & 13.7 & 88,200 & $1,208,300$ & 16.7 & 43,900 & 733,130 & 25.5 & 39,200 & 999,600 \\
\hline Subtotal-2, hydrocyclone & 76.0 & --- & $1,567,100$ & 66.0 & --- & 916,520 & 69.0 & --- & $1,245,300$ \\
\hline Balance-2, hydrocyclone & $100.0 \%$ & --- & $99.6 \%$ & $100.0 \%$ & --- & $105.2 \%$ & $100.0 \%$ & --- & $88.0 \%$ \\
\hline Underflow (intermediate) & 62.3 & 5,760 & 358,840 & 49.3 & 3,720 & 183,390 & 43.5 & 5,650 & 245,770 \\
\hline Clean sands (output) & 60.3 & 3,130 & 188,730 & 46.2 & 2,400 & 110,880 & 41.6 & 3,570 & 148,510 \\
\hline Froth (output) & 2.0 & 49,200 & 98,400 & 3.1 & 21,190 & 65,689 & 1.9 & 27,100 & 51,490 \\
\hline Subtotal-3, scrubbing-flotation & 62.3 & --- & 287,130 & 49.3 & --- & 176,560 & 43.5 & --- & 200,000 \\
\hline Balance-3, scrubbing-flotation & $100.0 \%$ & --- & $80.0 \%$ & $100.0 \%$ & --- & $96.3 \%$ & $100.0 \%$ & --- & $81.4 \%$ \\
\hline Total output & 100.0 & --- & $1,590,000$ & 100.0 & --- & 997,000 & 100.0 & --- & $1,310,000$ \\
\hline Balance & $100.0 \%$ & --- & $60.5 \%$ & $100.0 \%$ & --- & $63.1 \%$ & $100.0 \%$ & --- & $69.3 \%$ \\
\hline Clean products (calculated value) & 84.3 & 3,400 & 287,000 & 80.2 & 2,470 & 198,000 & 72.6 & 3,530 & 256,000 \\
\hline Sludge cake (calculated value) & 15.7 & 83,400 & $1,310,000$ & 19.8 & 40,400 & 799,000 & 27.4 & 38,300 & $1,050,000$ \\
\hline Clean products (clean sand+coarse) & $84.3 \%$ & --- & $18.1 \%$ & $80.2 \%$ & --- & $19.9 \%$ & $72.6 \%$ & --- & $19.5 \%$ \\
\hline Sludge cake (overflow+froth) & $15.7 \%$ & --- & $81.9 \%$ & $19.8 \%$ & --- & $80.1 \%$ & $27.4 \%$ & --- & $80.5 \%$ \\
\hline & Soil- & -RA-d (An & on) & Soil- & RA-e (Cat & ion) & Soil- & RA-i (Cati & on) \\
\hline Stream (input / output) & $\begin{array}{c}\text { Dry solids } \\
\text { (A) } \\
(\mathrm{kg})\end{array}$ & $\begin{array}{c}\text { Cs-total } \\
(\mathrm{B}) \\
(\mathrm{Bq} / \mathrm{kg})\end{array}$ & $\begin{array}{c}\mathrm{Bq} \\
(=\mathrm{A} \times \mathrm{B}) \\
(\mathrm{Bq})\end{array}$ & \begin{tabular}{|c|} 
Dry solids \\
(A) \\
(kg)
\end{tabular} & $\begin{array}{c}\text { Cs-total } \\
(\mathrm{B}) \\
(\mathrm{Bq} / \mathrm{kg}) \\
\end{array}$ & $\begin{array}{c}\mathrm{Bq} \\
(=\mathrm{A} \times \mathrm{B}) \\
(\mathrm{Bq})\end{array}$ & \begin{tabular}{|c|} 
Dry solids \\
(A) \\
(kg)
\end{tabular} & $\begin{array}{c}\text { Cs-total } \\
(\mathrm{B}) \\
(\mathrm{Bq} / \mathrm{kg}) \\
\end{array}$ & $\begin{array}{c}\mathrm{Bq} \\
(=\mathrm{A} \times \mathrm{B}) \\
(\mathrm{Bq})\end{array}$ \\
\hline Untreated feed soil (input) & 100.0 & 18,800 & $1,880,000$ & 100.0 & 13,200 & $1,320,000$ & --- & 15,700 & --- \\
\hline Coarse, $+4 \mathrm{~mm}$ (output) & 13.0 & 2,710 & 35,230 & 23.0 & 3,430 & 78,890 & --- & --- & --- \\
\hline Coarse, $+2-4 \mathrm{~mm}$ (output) & 14.0 & 13,400 & 187,600 & 10.0 & 4,200 & 42,000 & --- & --- & --- \\
\hline Feed $<2 \mathrm{~mm}$ (intermediate) & 73.0 & 20,700 & $1,511,100$ & 67.0 & 20,600 & $1,380,200$ & --- & 22,400 & --- \\
\hline Subtotal-1, screens & 100.0 & --- & $1,733,900$ & 100.0 & --- & $1,501,100$ & --- & --- & --- \\
\hline Balance- 1 , screens & $100.0 \%$ & --- & $92.2 \%$ & $100.0 \%$ & --- & $113.7 \%$ & --- & --- & --- \\
\hline Feed<2mm (intermediate) & 73.0 & 20,700 & $1,511,100$ & 67.0 & 20,600 & $1,380,200$ & --- & 22,400 & --- \\
\hline Underflow (intermediate) & 58.4 & 5,540 & 323,530 & 49.0 & 6,560 & 321,440 & --- & 5,240 & --- \\
\hline Overflow (output) & 14.6 & 74,600 & $1,089,100$ & 18.0 & 34,400 & 619,200 & --- & 29,100 & --- \\
\hline Subtotal-2, hydrocyclone & 73.0 & --- & $1,412,600$ & 67.0 & --- & 940,640 & --- & --- & --- \\
\hline Balance-2, hydrocyclone & $100.0 \%$ & --- & $93.5 \%$ & $100.0 \%$ & --- & $68.2 \%$ & --- & --- & --- \\
\hline Underflow (intermediate) & 58.4 & 5,540 & 323,530 & 49.0 & 6,560 & 321,440 & --- & 5,240 & --- \\
\hline Clean sands (output) & 53.2 & 2,840 & 151,080 & 48.2 & 3,670 & 176,890 & --- & 1,160 & --- \\
\hline Froth (output) & 5.2 & 17,500 & 91,000 & 0.8 & 29,900 & 23,920 & --- & 22,500 & --- \\
\hline Subtotal-3, scrubbing-flotation & 58.4 & --- & 242,080 & 49.0 & ---- & 200,810 & --- & --- & --- \\
\hline Balance-3, scrubbing-flotation & $100.0 \%$ & --- & $74.8 \%$ & $100.0 \%$ & --- & $62.5 \%$ & --- & --- & --- \\
\hline Total output & 100.0 & --- & $1,550,000$ & 100.0 & "--- & 941,000 & ב--- & ב--- & ---- \\
\hline Balance & $100.0 \%$ & --- & $82.4 \%$ & $100.0 \%$ & --- & $71.3 \%$ & --- & --- & --- \\
\hline Clean products (calculated value) & 80.2 & 4,660 & 374,000 & 81.2 & 3,670 & 298,000 & --- & --- & --- \\
\hline Sludge cake (calculated value) & 19.8 & 59,600 & $1,180,000$ & 18.8 & 34,200 & 643,000 & --- & --- & --- \\
\hline Clean products (clean sand+coarse) & $80.2 \%$ & --- & $24.1 \%$ & $81.2 \%$ & --- & $31.6 \%$ & --- & --- & --- \\
\hline Sludge cake (overflow+froth) & $19.8 \%$ & --- & $75.9 \%$ & $18.8 \%$ & --- & $68.4 \%$ & --- & --- & --- \\
\hline
\end{tabular}

Balance of radio-Cs (Bq); $\square: 80 \sim 120 \%, \quad \square: 60 \sim 80 \%$ or $120 \sim 140 \%, \quad \square:$ under $60 \%$

12,400 Bq/kg と非常に高い值であった. Soil-PG-eのみが高 い理由は不明である. 図-6(B)に示したように， soil-PG-e 以外のsoil-PGの2〜4mm粗粒子分は, 920〜4,270 Bq/kg (ave. 2,210 Bq/kg)であり，除去率は69.5～97.9\% (ave. 88.2\%)であ つた. またsoil-RAの4〜 40mm粗粒子分の含有放射能量は 580〜3,430 Bq/kg (ave. 1,840 Bq/kg)であり，除去率は74.1〜 96.9\% (ave. 88.9\%)であった. Soil-PGの2〜4mmと soil-RAの4 〜 40mmの粗粒子分については, フルイによる分級操作 のみで概ね3,000 Bq/kg以下になることが認められた。一 方, soil-RAの2〜4mm粗粒子分は, 4,200〜 13,400 Bq kg (ave. 7,490 Bq $\mathrm{kg}$ ) と高く，除去率は29.0〜 75.9\% (ave. 59.1\%)
と他の粗粒子分に比べて低い值であった.

図-7に含有放射能量の除去率と濃縮残椬の発生量の関 係を示す．ハイドロサイクロンまでの分級処理のみのプ ロットとスクラビング・フローテーションによる洗浄処 理を加えた場合のプロットを関連付けて示した. フロス の発生量はsoil-PGで元土壤の $1.2 〜 6.1 \%$ (ave. 3.7\%), soilRAで $0.8 〜 5.2 \%$ (ave. 2.6\%)であった. スクラビング・フロ 一テーションは除去率を70\%前後から84～87\% へと大き く改善させても, 濃縮残椬は僅か数\%しか増加しないこ とがわかった. スクラビング・フローテーションは，物 理的な研磨処理では困難であった高い除去率と高い減容 


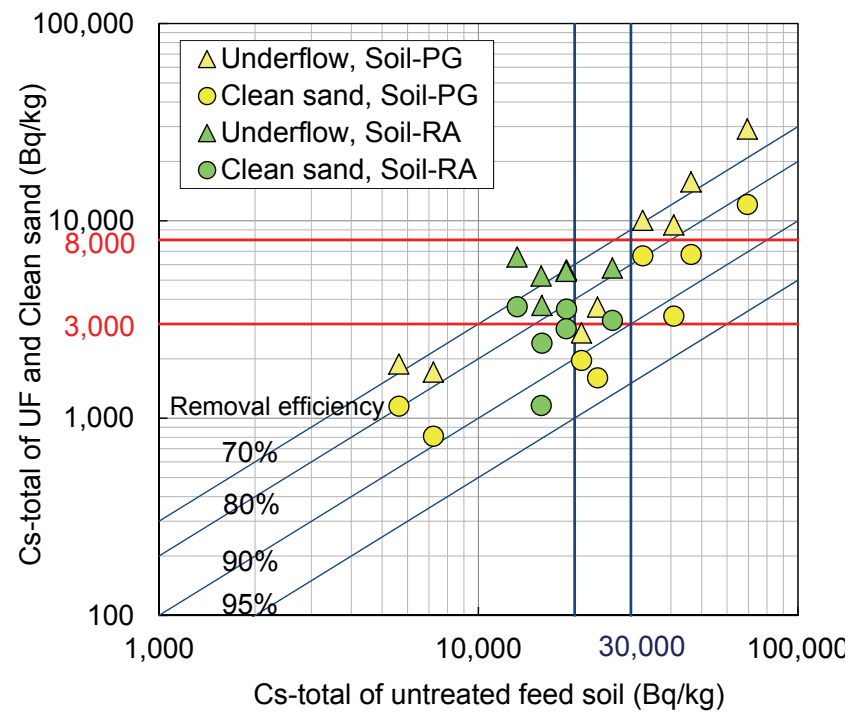

(A) Underflow and Clean sand vs. feed soil

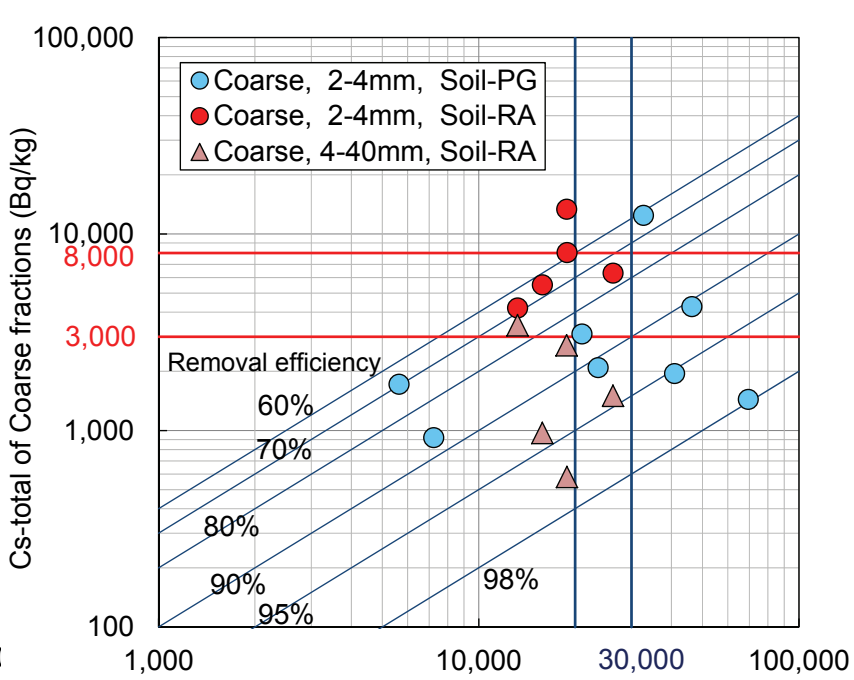

Cs-total of untreated feed soil $(\mathrm{Bq} / \mathrm{kg})$ (B) Coarse fractions (2-4mm, 4-40mm) vs. feed soil

図-6 元土㙥の含有放射能量とアンダーフロー(UF), 洗浄土，粗粒子分の含有放射能量との関係

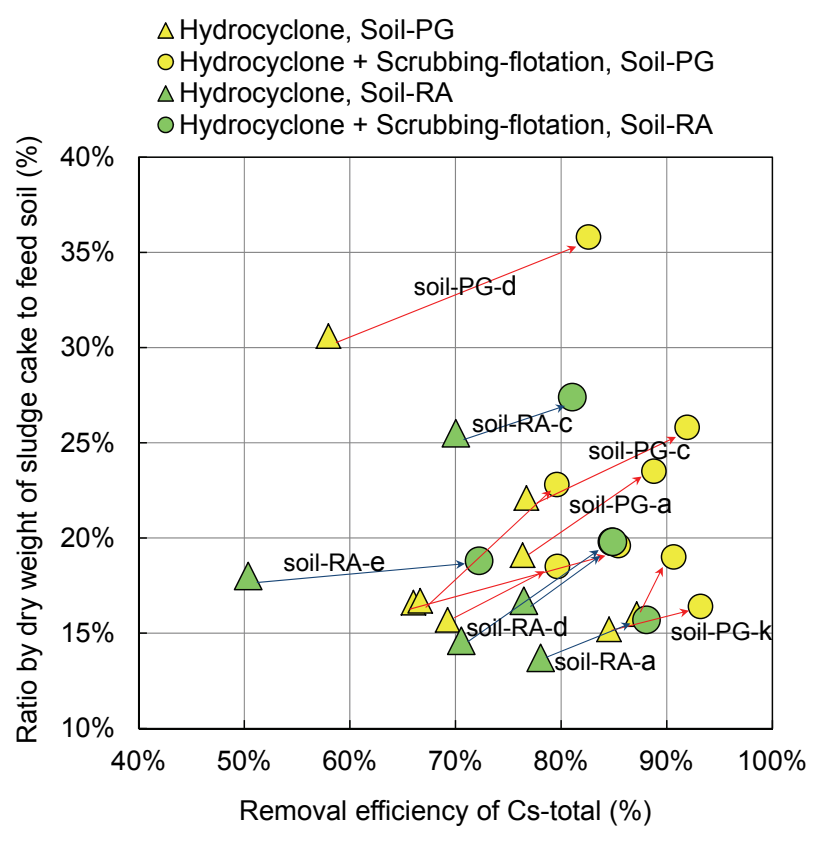

図-7 含有放射能量除去率と濃縮残椬発生量の関係

率の両立に極めて有効な技術であると考えられる.

次に洗浄土と粗粒子分の浄化産出物(clean products) と濃 縮残渣(sludge cake)について検討寸る. 土壌洗浄によって 産出された粗粒子分, 洗浄土, OF, およびフロスの放射性 Cs量の合計を $100 \%$ とした場合の浄化産出物(洗浄土十粗 粒子分) と濃縮残椬 $(\mathrm{OF}+$ フロス)の放射性Cs量(Bq)の分配 割合を計算し表-2と表-3の未尾に示した. 図-8に浄化産 出物と濃縮残渣の発生量と放射性 $\mathrm{Cs}$ 量(Bq)の分配割合を 示寸，浄化産出物と濃縮残椬が，発生量と放射性Cs量の 両方においてトーレードオフの関係にあることが認めら れる. Soil-PGでは, 浄化産出物は土壌量の $64.2 \sim 83.6 \%$ (ave. 77.3\%), 放射性Cs量の5.1〜27.1\% (ave. 12.5\%)占め, 濃縮残渣は土袞量の $16.4 \sim 35.8 \%$ (ave. 22.7\%), 放射性Cs量

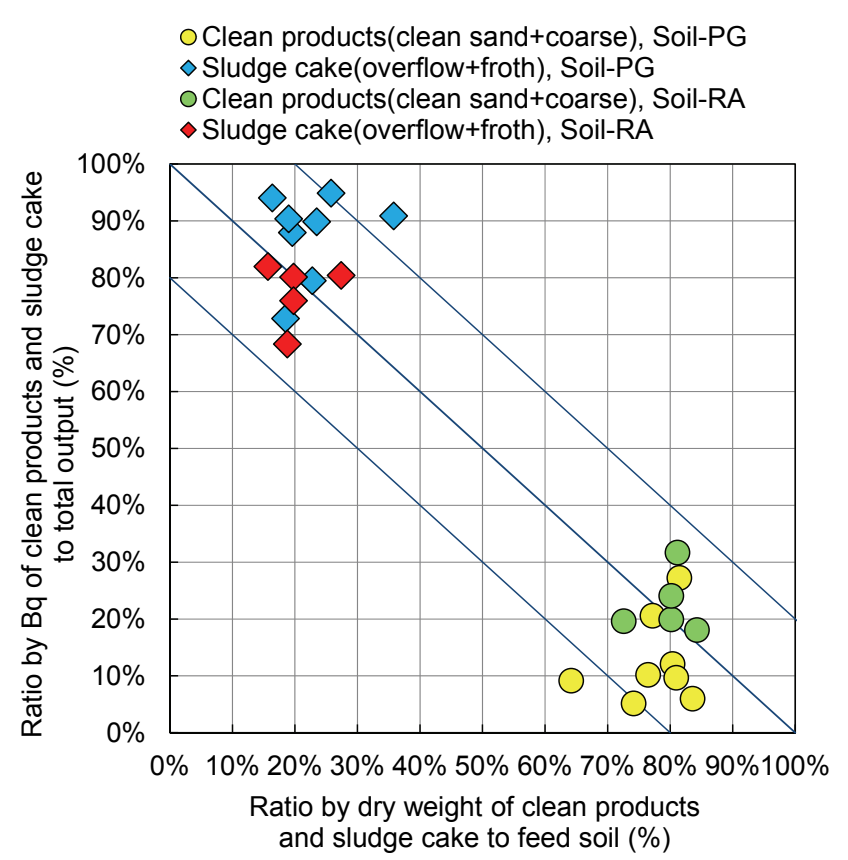

図-8 浄化産出物と濃縮残椬の発生量と放射性Cs量の分配割合

の72.9〜94.9\% (ave. 87.5\%)を占めた. 同様にsoil-RAでは, 浄化産出物は土袞量の72.6 $84.3 \%$ (ave. 79.7\%), 放射性Cs 量の18.1 31.6\% (ave. 22.6\%) を占め, 濃縮残椬は土壤量の 15.7 27.4\% (ave. 20.3\%), 放射性Cs量の 68.4〜 81.9\% (ave. $77.4 \%$ )を占めた．以上より，(a)土袞量の約 $80 \%$ が浄化産 出物，約 $20 \%$ が濃縮残渣となること，(b)約 $20 \%$ の濃縮残 渣に放射性Cs量の77〜88\%が集約されることがわかった。

\section{(5) 粗粒子分の軽質分除去による含有放射能量の低減}

Soil-RA-a 〜eの元土㗒, 洗浄土, 濃縮残渣, および粗 粒子分の強熱減量値を表-4(A)に示す．元土壌は $8.8 〜$ $16.9 \%$ (ave. 10.9\%), 洗浄土は1.3〜2.3\% (ave. 1.7\%), 濃縮残 椬は23.4〜32.2\% (ave. 28.1\%), 2〜 4mm粗粒子分は5.8〜 
11.1\% (ave. 8.1\%)，および4〜40mm 粗粒子分は2.0〜 7.0\% (ave. 4.0\%)であった. 元土㙋中の有機物のほとんどは洗 浄処理によって濃縮残椬に集約されること，2～4mm粗 粒子分には多くの有機物が混入していることが認められ た. 含有放射能量は2 4mm粗粒子分が $4,200 \sim 13,400$ $\mathrm{Bq} / \mathrm{kg}$ (ave. 7,300 Bq/kg)，4～40mm粗粒子分が580〜3,430 Bq/kg (ave. 1,800 Bqkg)であることから，有機物が放射性 Csを吸着していることが示唆された。目視によると2〜 $4 \mathrm{~mm}$ 粗粒子分には, 分解が進んでいる枯葉や植物片など の軽質分が多数混入していること，4～40 mm粗粒子分に は小枝などの植物片が含まれていること等が観察された。 Soil-RA-f〜hの3試料についてもフルイ分級を行ない，粗 粒子分の強熱減量と含有放射能量の分析值を表-4(A)に 追加した．2４mm粗粒子分については， soil-RA-fの強熱 減量が32.5\%, 含有放射能量が20,230 Bq/kg と高い值であ つたが，他の2試料は強熱減量が $6.7 〜 8.7 \%$, 含有放射能 量が8,910 9,660 Bq/kg と前述の5試料(soil-RA-a 〜e) と同程 度であった．4～40mm粗粒子分は， soil-RA-hの含有放射 能量が8,150 Bq/kg と他の試料に比べて高い值であった。
植物片等の軽質分の含有放射能量と軽質分の除去によ る含有放射能量の低減効果を把握するために，傾斜法に よる軽質分の分離試験を実施した。傾斜法によって粗粒 子分は，砂利(gravel)を主体とする沈殿物(deposit)と植物片 等の軽質分(light fraction)に分離された. 結果を表-4(B)と 図-9に示す．図-9中の曲線は，分離前の含有放射能量の $40 \%, 80 \%, 200 \%(2 \times), 600 \%(6 \times)$ の值を示している. 沈殿 物と分離された軽質分の乾燥重量比率は, soil-RA-fを除 いて77:23〜95:5 (ave. 87:13)であった。 強熱減量值が32.5\% と非常に高いsoil-RA-fについては，36\%の軽質分が分離 された. 図-9と表-4(B)に示すようにsoil-RA-hの2〜 4mm を除いて，(a)軽質分が分離されたことによって粗粒子分 の含有放射能量の 20 ～60\%が除去されること，(b)分離さ れた軽質分(有機物)の含有放射能量は $12,000 ５ 0,000$ $\mathrm{Bq} / \mathrm{kg}$ と分離前の粗粒子分の 2 6倍と高いこと, (c) 分離 後の粗粒子分の強熱重量は $1.7 \sim 3.2 \%$ と運動場土壌並み の低い值になることがわかった．なお， soil-RA-hの2〜 $4 \mathrm{~mm}$ 粗粒子分については，原因は不明であるが分離前後 で含有放射能量值が逆転した。

表-4 住宅地等の除染除去土壌(Soil-RA)の粗粒子分中の軽質分除去による含有放射能量の低減

(A) Ignition loss (\%) and Cs-total (Bq/kg) of coarse fractions

\begin{tabular}{|c|c|c|c|c|c|c|c|}
\hline \multirow[b]{2}{*}{ Soil-RA } & \multicolumn{5}{|c|}{ Ignition loss (\%) } & \multicolumn{2}{|c|}{ Cs-total (Bq/kg) } \\
\hline & $\begin{array}{c}\text { Feed } \\
\text { soil }\end{array}$ & $\begin{array}{l}\text { Clean } \\
\text { sand }\end{array}$ & $\begin{array}{l}\text { Sludge } \\
\text { cake }\end{array}$ & $\begin{array}{l}\text { Coarse, } \\
2-4 \mathrm{~mm}\end{array}$ & $\begin{array}{l}\text { Coarse, } \\
4-40 \mathrm{~mm}\end{array}$ & $\begin{array}{l}\text { Coarse, } \\
2-4 \mathrm{~mm}\end{array}$ & $\begin{array}{l}\text { Coarse, } \\
4-40 \mathrm{~mm}\end{array}$ \\
\hline$a$ & $8.8 \%$ & $1.3 \%$ & $23.4 \%$ & $7.4 \%$ & $7.0 \%$ & 6,320 & 1,500 \\
\hline$b$ & $11.2 \%$ & $1.4 \%$ & $32.2 \%$ & $8.1 \%$ & $2.0 \%$ & 5,510 & 970 \\
\hline c & $16.9 \%$ & $2.0 \%$ & $31.3 \%$ & $8.1 \%$ & $2.5 \%$ & 8,040 & 580 \\
\hline d & $8.9 \%$ & $2.3 \%$ & $24.2 \%$ & $11.1 \%$ & $5.5 \%$ & 13,400 & 2,710 \\
\hline e & $8.5 \%$ & $1.4 \%$ & $29.3 \%$ & $5.8 \%$ & $2.9 \%$ & 4,200 & 3,430 \\
\hline$f$ & $20.9 \%$ & -- & -- & $32.5 \%$ & -- & 20,200 & -- \\
\hline g & $13.7 \%$ & -- & -- & $6.7 \%$ & $6.0 \%$ & 8,910 & 2,600 \\
\hline $\mathrm{h}$ & $14.8 \%$ & --- & --- & $8.7 \%$ & $4.5 \%$ & 9,660 & 8,150 \\
\hline
\end{tabular}

(B) Removal effect of light fraction (organic etc) in coarse fractions

\begin{tabular}{|c|c|c|c|c|c|c|c|}
\hline \multirow{2}{*}{$\begin{array}{l}\text { Soil-RA, } \\
\text { Coarse } \\
\text { fractions }\end{array}$} & \multicolumn{2}{|c|}{ Ratio by dry weight (\%) } & \multicolumn{3}{|c|}{ Deposit } & \multicolumn{2}{|c|}{ Light fraction } \\
\hline & $\begin{array}{l}\text { Deposit } \\
\text { (gravel) }\end{array}$ & $\begin{array}{l}\text { Light fraction } \\
\text { (organic etc) }\end{array}$ & $\begin{array}{l}\text { Cs-total } \\
(\mathrm{Bq} / \mathrm{kg})\end{array}$ & $\begin{array}{l}\text { Removal } \\
\text { ratio (\%) }\end{array}$ & $\begin{array}{l}\text { Ignition } \\
\text { loss (\%) }\end{array}$ & $\begin{array}{l}\text { Cs-total } \\
\text { (Bq/kg) }\end{array}$ & $\begin{array}{l}\text { Ignition } \\
\text { loss (\%) }\end{array}$ \\
\hline a, $2-4 \mathrm{~mm}$ & $91.3 \%$ & $8.7 \%$ & 3,510 & $44.5 \%$ & $1.7 \%$ & 39,100 & $28.2 \%$ \\
\hline b, $2-4 \mathrm{~mm}$ & $89.8 \%$ & $10.2 \%$ & 3,200 & $41.9 \%$ & $2.2 \%$ & 25,500 & $53.5 \%$ \\
\hline c, $2-4 \mathrm{~mm}$ & $77.2 \%$ & $22.8 \%$ & 4,110 & $48.9 \%$ & $2.1 \%$ & 35,200 & --- \\
\hline $\mathrm{d}, 2-4 \mathrm{~mm}$ & $80.7 \%$ & $19.3 \%$ & 6,760 & $49.6 \%$ & $3.0 \%$ & 49,900 & $17.0 \%$ \\
\hline e, $2-4 \mathrm{~mm}$ & $88.2 \%$ & $11.8 \%$ & 3,980 & $5.2 \%$ & $2.3 \%$ & 12,800 & -- \\
\hline f, $2-4 \mathrm{~mm}$ & $64.4 \%$ & $35.6 \%$ & 8,460 & $58.1 \%$ & $2.8 \%$ & 42,100 & $82.2 \%$ \\
\hline h, $2-4 \mathrm{~mm}$ & $84.4 \%$ & $15.6 \%$ & 13,100 & $-35.6 \%$ & $2.8 \%$ & 45,100 & -- \\
\hline h, $4-40 \mathrm{~mm}$ & $95.0 \%$ & $5.0 \%$ & 6,080 & $25.4 \%$ & $3.2 \%$ & 20,600 & -- \\
\hline
\end{tabular}

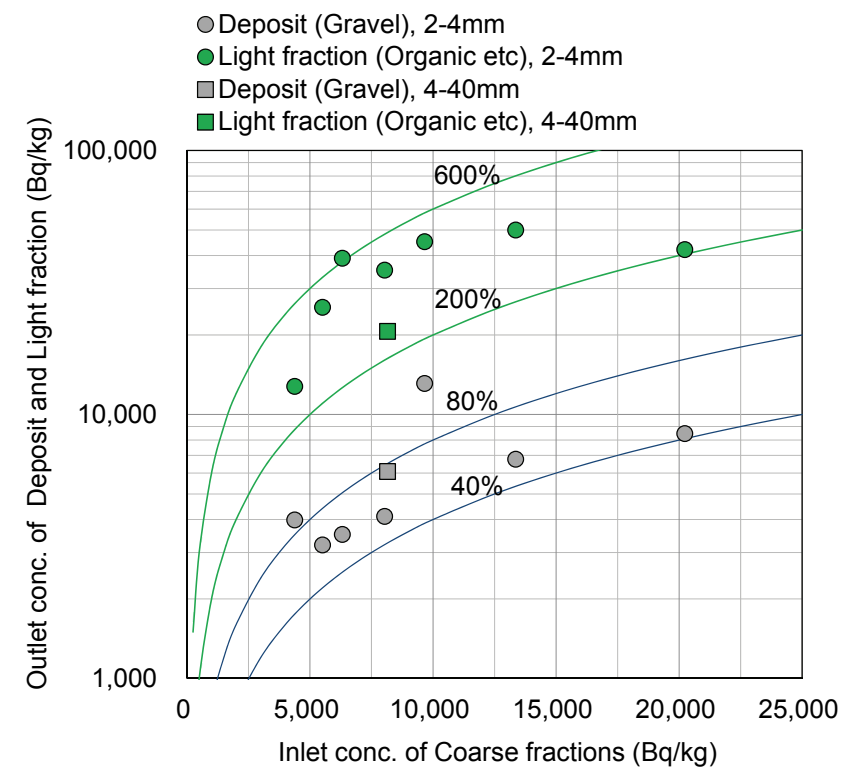

図-9 粗粒子分中の軽質分除去による含有放射能量の低減効果

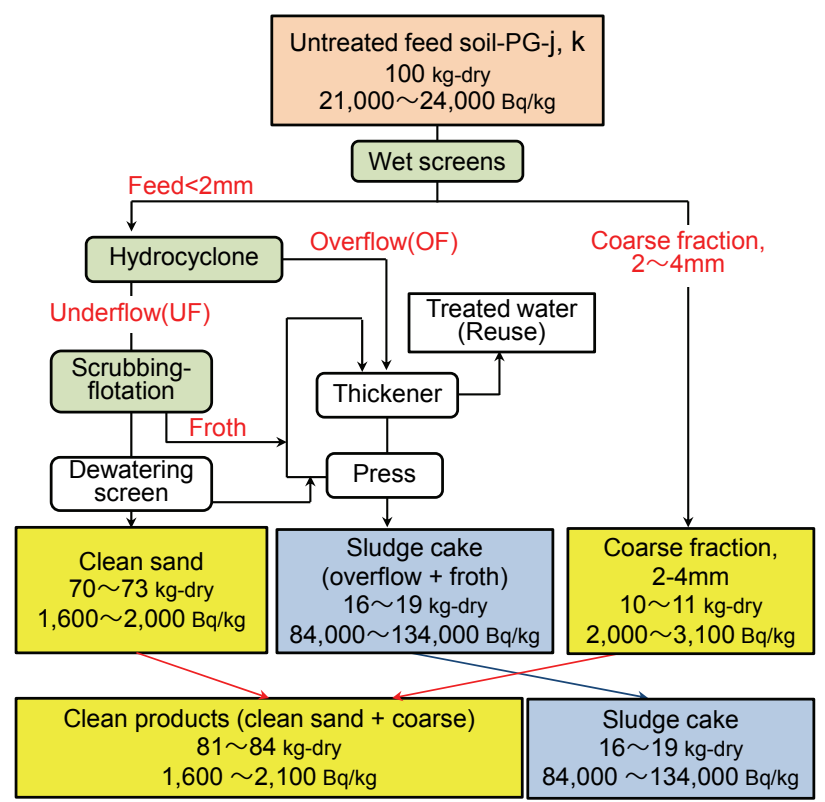

図-10 土袞洗浄による運動場土壤(soil-PG)の浄化・減容化効果 
一部の例外があるものの軽質分を分離することで，含 有放射能量の $20 \sim 60 \%$ 除去され，分離後の粗粒子分の 強熱重量は1.7〜3.2\%と低い值となることが判明した.

\section{5. 浄化 · 減容化の効果の評価}

土壌洗浄による放射性Cs污染土壤の浄化・減容化効果 を理解するために，表-2と表-3の中から各プロセスの放 射性 $\mathrm{Cs}$ 量 $(\mathrm{Bq})$ の収支が良好であり，元土壌の放射性Csが 20,000 Bqkg前後であったsoil-PG-j, k と soil-RA-c, d $の 4$ 試料を 選び図-10, 図-11に整理して示した. 20,000 Bqkg前後の 元土壌を選んだのは, soil-PGと soil-RAの比較を容易に行 なうためである．なお，サイクロンOFを主体とする洗 浄排水の凝集沈殿処理水の放射性Cs濃度はsoil-PG, soilRA共通して全て定量下限值未満( $<10 \mathrm{~Bq} \mathrm{~kg}$ ) であった.

図-10に示したように100 kgのsoil-PG-j, k (21,000〜24,000 $\mathrm{Bq} / \mathrm{kg}$ )の洗浄処理を行なうと, $1,600 \sim 2,000 \mathrm{~Bq} / \mathrm{kg}$ の洗浄 土が70〜73 kg, 84,000〜134,000 Bq kgの濃縮残椬が16〜19 $\mathrm{kg}, 2,000 \sim 3,100 \mathrm{~Bq} \mathrm{~kg} の 2 \sim 4 \mathrm{~mm}$ 粗粒子分が10 $11 \mathrm{~kg}$ 産出 された. 洗浄土と粗粒子分を併せた浄化産出物 $81 \sim 84 \mathrm{~kg}$ の含有放射能量は1,600〜2,100 Bq $\mathrm{kg}$ となった.

Soil-RA-c, dについては，粗粒子分中の軽質分除去によ る含有放射能量の低減効果を考慮に入れて図-11を作成 した. $100 \mathrm{~kg}$ のsoil-RA-c, d (18,800 18,900 Bqkg)の洗浄処 理を行なうと， $2,800 〜 3,600 \mathrm{~Bq} / \mathrm{kg}$ の洗浄土が $42 \sim 53 \mathrm{~kg}$, $38,000 \sim 60,000 \mathrm{~Bq} / \mathrm{kg}$ の濃縮残渣が20〜27 kg，600〜2,700 $\mathrm{Bq} \mathrm{kg}$ の 4 40mm粗粒子分が $13 \sim 19 \mathrm{~kg}, 8,000 \sim 13,400$ $\mathrm{Bq} \mathrm{kg}$ の2 4mm粗粒子分が12〜14 kg産出された. 軽質分 除去によって2〜 $4 \mathrm{~mm}$ 粗粒子分の含有放射能量は8,000〜
13,400 Bq $\mathrm{kg}$ から4,100〜6,800 Bq $\mathrm{kg}$ に低減された. 回収さ れた2〜 $4 \mathrm{~mm}$ 砂利の量は9〜11 kgであった. 除去された軽 質分量は2.7〜2.8 kgであり，その含有放射量は35,000〜 50,000 Bqkgであった. 洗浄土と粗粒子分を併せた $70 〜 78$ $\mathrm{kg}$ の浄化産出物の含有放射能量は2,800〜3,400 Bq $\mathrm{kg}$ とな り，軽質分を併せた $22 \sim 30 \mathrm{~kg}$ の濃縮残渣の含有放射能量 は38,000〜 58,000 Bqkgとなった.また，強熱減量の值か らは元土壤の有機物のほとんどが濃縮残椬(軽質分を含 む)に集約され，浄化産出物の強熱減量は2 3\%と運動 場土壌並みの低い值となった。

以上より, 土㙵洗浄による放射性Cs污染土袞(soil-PG, soil-RA)の浄化効果は非常に高く, 20,000 Bq $/ \mathrm{kg}$ 前後の元 土畩から概ね $23,000 \mathrm{~Bq} / \mathrm{kg}$ 以下の浄化産出物が得られるこ と, 減容化効果も高 $<$, 元土壌の $70 \sim 80 \%$ を浄化産出物 として回収できることが判明した.

\section{6. まとめ}

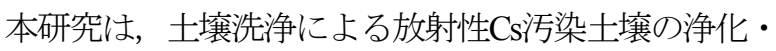
減容化効果を把握することを目的に, 各洗浄プロセスの 放射性Cs量の収支を検討した上で, 浄化・減容化効果の 評価を行なった. 主な結果を以下に記す。

1）ハイドロサイクロンによる分級処理は，除去率のバ ラツキが大きい上に平均的な除去率が $70 \%$ 前後に止 まった．スクラビング・フローテーションによる化 学的な洗浄処理を追加することによって, 除去率の バラツキは小さくなり, 平均的な除去率は $84 \sim 87 \%$ へと大幅に改善された。

2) スクラビング・フローテーションは除去率を $70 \%$ 前

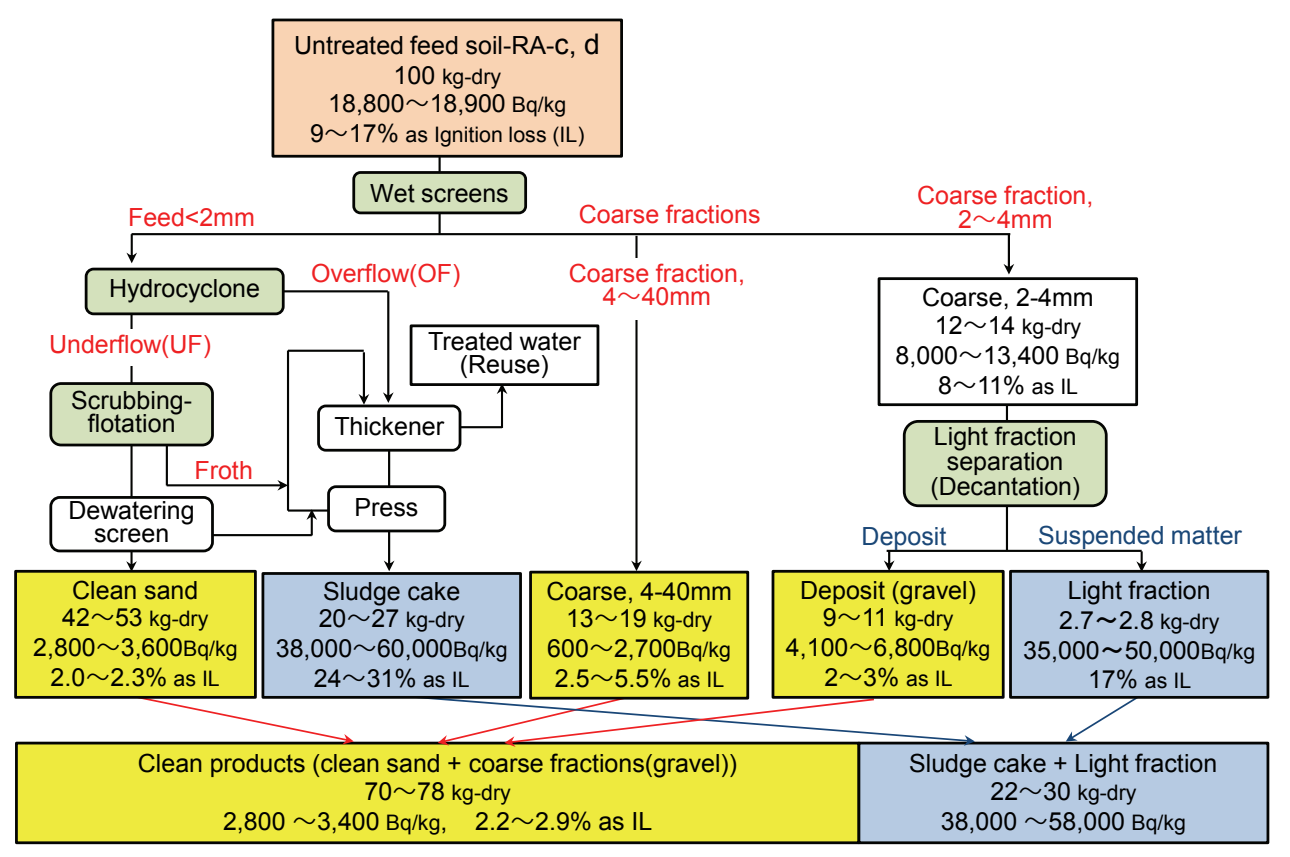

図-11 土壌洗浄による住宅地等の除染除去土壌(soil-RA)の浄化・減容化効果 
後から 84〜87\%へと大きく改善させても，濃縮残椬 は僅か数\%しか増加しないことがわかった．スクラ ビング・フローテーションは, 高い除去率と高い減 容率の両立に極めて有効な技術であると考えられる.

3）洗浄土の目標を3,000 Bq kg とした場合には，soil-PGと soil-RAの両方において，20,000〜30,000 Bq kgまで浄化 可能であること，目標を8,000 Bq $\mathrm{kg}$ とした場合には, soil-PGであれば約50,000 Bq $\mathrm{kg}$ までが浄化可能である ことがわかった。

4) 浄化産出物 (洗浄土十粗粒子分) と濃縮残椬は，発生 量と放射性Cs量の両方においてトレードオフの関係 にある．放射性CS污染土㙥量の約 $80 \%$ が浄化産出物， 約 $20 \%$ が濃縮残渣となること，約 $20 \%$ の濃縮残渣に 放射性Cs量の77〜88\%が集約されることが判明した。

5) Soil-RAの粗粒子分には，分解の進んでいる枯葉や植 物片などの軽質分が多数混入していること，これら の軽質分の含有放射能量はかなり高いこと, 軽質分 を分離することによって粗粒子分の含有放射能量の 20～60\%が除去されることがわかった.

6) 粗粒子分中の軽質分の分離プロセス(ログウォッシャ 一を想定)も考慮に入れて土壌洗浄による放射性CS污 染土壤の浄化・減容化効果の評価を行なった. 浄化 効果は非常に高 $<20,000 \mathrm{~Bq} / \mathrm{kg}$ 前後の元土壌から概社 3,000 Bqkg以下の浄化産出物が得られること, 減容 化効果も高く元土壌の 70 ～80\%を浄化産出物として 回収できることが判明した．また，元土袞中の有機 物のほとんどが濃縮残椬(軽質分を含む)に集約され, 浄化産出物の強熱減量は2～3\% と運動場土壌並みの 低い值となることがわかった。

謝辞 : 本研究の実施に当たって，清水建設株式会社の高 木光雄氏，嶋田智郎氏，および樋口義弘氏からは放射性 Cs污染土䁃の採取と実験の実施に当たって多大な協力を 頂いた．技術研究所の中尾徳晶博士からは放射線防護に 関する有益な助言を頂いた。帝人エコ・サイエンス株式 会社の森川航平氏からは一連の実験的検討において多大 な実務的な協力を受けた．なお，本研究の一部は，環境 省の「平成24年度（平成23年度からの繰越分）除染技術 実証事業（その5）」の一環として実施した.

ここに記して謝意を表します。

\section{参考文献}

1) 環境省: 除染関係ガイドライン(第 2 版, 平成 25 年 5 月), pp.2-5 pp.2-126, 2013.

2) 環境省除染情報サイト：中間貯蔵施設について, http://josen.env.go.jp/soil/interim_storage_facility.html.

3) 井出一貴, 三浦俊彦, 神徳敬, 高田尚哉 : 放射能污染土 㙵の分級洗浄処理, 大林組技術研究所報, No.76, pp.1-6, 2012.
4) 舟川将史, 田川明広, 奥田信康 : 植物が混入した放射 性セシウム污染土壤の多段階土壌洗浄処理試験, 日本 原子力学会和文論文誌, Vol.11, No.4, pp.272-280, 2012.

5) 中島卓夫, 田川明広, 松生隆司, 大山将, 林茂郎, 高馬 崇：放射性セシウム污染土猿の洗浄処理に関する検 討, 鴻池組技術研究報告, Vol.22, pp.1-8, 2012.

6)田中真弓, 川端淳一, 大塚誠治, 河合達司, 小澤一喜 : 放射性セシウム含有土壤の原位置湿式分級洗浄・磨 洗効果について, 第 19 回地下水・土䁃污染とその防 止対策に関する研究集会(CD-ROM), S6-20, pp.594-597, 2013.

7) 山本達生, 岩田将英, 野田兼司, 清水英樹, 芝本真尚 : 放射性物質により污染された土壤の小型・簡易設備 による減容化処理技術の開発, 第 20 回地下水・土壤 污染とその防止対策に関する研究集会(CD-ROM), S3-24, pp.333-338, 2014.

8) 友口勝, 早澤敬一, 渡邊亮栄, 鎌田雅美 : 放射性セシウ ム含有土㙵の処理について, 第 19 回地下水・土袞污 染とその防止対策に関する研究集会(CD-ROM), S4-20, pp.384-388, 2013.

9) 毛利光男：スクラビング・フローテーションを用い た土壌洗浄法による放射性物質污染土壤の効率的な 浄化と減容化, 建設の施工企画, No.754, pp.65-71, 2012.

10）毛利光男, 土田充, 馬場直紀, 中嶋卓磨 : 土壌洗浄法に よる放射性物質污染土壤の浄化・減容化および濃縮 残渣処理の自動化, 環境放射能除染学会誌, Vol.1, No.3, pp.213-219, 2013.

11）伊藤健一, 宮原英貴, 氏家亨, 武島俊達, 横山信吾, 中田 弘太郎, 永野哲志, 佐藤努, 八田珠郎, 山田裕久: 湿式 分級洗浄および天然鉱物等による農地土㙵等に含ま れる放射性セシウム除去方法の実践的検討, 日本原子 力学会和文論文誌, Vol.11, No.4, pp.255-271, 2012.

12）高橋勇介, 藤井隆夫, 島長義, 石井和之, 工藤一秋, 立間 徹, 藤田洋崇, 佐藤理夫, 迫田章義 : 污染土壤加放 射性セシウムの除去・回収, 生産研究, Vol.66, No.4, pp.81-87, 2014.

13）保高徹生, 川本徹, 駒井武 : 放射性セシウム含有土壤 一の酸抽出方法の適用性に関寸る基礎的検討, RADIOISOTOPES, Vol.62, No.4, pp.211-218, 2013.

14）時澤孝之, 長沼政喜, 青木勝己, 長安孝明, 佐藤和彦, 山 下照雄, 小林秀和, 横澤拓磨, 永井崇之, 藤田博喜, 菊池 政昭, 横山裕也 : 土壌の原位置加熱による放射性セシ ウムの除去可能性の検討, 日本原子力研究開発機構 JAEA-Research (Web), No.2011-026, pp.1-74, 2011.

15) 大山将, 中島卓夫, 松生隆司: 放射性セシウム含有土 壤の加熱処理に関する基礎検討, 第 19 回地下水 - 土 壌污染とその防止対策に関する研究集会(CD-ROM), S2-21, pp.176-179, 2013.

16) Dermont, G., Bergeron, M., Mercier, G. and RicherLafleche, M. : Soil washing for metal removal: A review of physical/chemical technologies and field applications, Journal of Hazardous Materials, Vol.152, No.1, pp. 1-31, 2008.

17) USEPA : Innovative site remediation technology, Soil Washing/Soil Flushing, 542-B-93-012, pp.3.1-3.35, 1993.

18）環境省 除染技術検索サイト：除染技術実証事業等, https://www2.env.go.jp/dtox/info/proof.

19）毛利光男, 馬場直紀, 土田充, 保坂幸一, 佐藤大樹, 中嶋 卓磨：ログウォッシャーによる粗粒子分からの軽質 
分の効果的な分離, 第 21 回地下水・土壤污染とその 防止対策に関する研究集会(CD-ROM), S2-20, pp.185190, 2015.

20) 毛利光男, 馬場直紀, 土田充, 中嶋卓磨 : 表面吸着モデ ルによる土塆中の放射性 Cs 分布特性の解析, 土木学 会論文集 G(環境), Vol.71, No.1, pp.26-38, 2015.

21) 山口紀子, 高田裕介, 林健太郎, 石川覚, 倉俣正人, 江口
定夫, 吉川省子, 坂口敦, 朝田景, 和穎朗太, 牧野知之, 赤羽幾子, 平舘俊太郎: 土壤一植物系における放射性 セシウムの挙動とその変動要因, 農業環境技術研究所 報告, Vol.31,pp.75-129, 2012.

(2015. 4. 10 受付)

\title{
MASS-BALANCE ANALYSIS AND PERFORMANCE EVALUATION OF RADIOCESIUM CONTAMINATED SOIL WASHING
}

\author{
Mitsuo MOURI, Naoki BABA, Mitsuru TSUCHIDA and Takuma NAKAJIMA
}

Soil washing is seen as a volume reduction/waste minimization technology for treatment of radiocesium (radio-Cs) contaminated soils. However, little information relative to specific application and potential effectiveness of the soil washing process exists that applies to radio-Cs contaminated soils in Fukushima. The objective of this experimental study was to understand the performance and validity of soil washing for the radio-Cs contaminated soils. Soil washing performance with a trade-off between the removal efficiency of radio-Cs and the volume reduction rate of feed soils was evaluated after an examination of each radio-Cs balance at every stage of soil washing, namely wet-sieving, hydrocyclone, and scrubbing-flotation.

As a result of this study, following observations were made; 1 ) the removal efficiencies of cyclone system were at around $70 \%$ of radio-Cs, and the efficiencies were greatly improved to $84 \sim 87 \%$, when the cyclone system was combined with the scrubbing-flotation system, 2) the sludge volume was slightly increased when the cyclone system was combined with the 'chemical scrubbing-flotation'. 3) 'chemical scrubbing-flotation' was useful for improving the removal efficiencies of radio-Cs as well as minimizing the sludge volume, 4) the treated water was good for reuse, because the radio-Cs was below the detectable level $(<10 \mathrm{~Bq} / \mathrm{kg}), 5)$ the radio-Cs content of clean products was less than $3,000 \mathrm{~Bq} / \mathrm{kg}$ as compared to the feed soils of approximate $20,000 \mathrm{~Bq} / \mathrm{kg}, 6)$ the volume reduction rate of feed soils ranged from 70 to $80 \%$, and 7) most of the organic matter in feed soils was concentrated into sludge cake.

The above results indicate that the soil washing system with the chemical scrubbing flotation makes it possible to achieve both high removal efficiency of radio-Cs and a high volume reduction rate of feed soils, and can be practically used in Fukushima for remediation of soils. 